Portland State University

PDXScholar

10-31-1968

\title{
An Analysis and Evaluation of the American Electoral College
}

Norma N. Williams

Portland State University

Follow this and additional works at: https://pdxscholar.library.pdx.edu/open_access_etds

Part of the American Politics Commons

Let us know how access to this document benefits you.

\section{Recommended Citation}

Williams, Norma N., "An Analysis and Evaluation of the American Electoral College" (1968). Dissertations and Theses. Paper 583.

https://doi.org/10.15760/etd.583

This Thesis is brought to you for free and open access. It has been accepted for inclusion in Dissertations and Theses by an authorized administrator of PDXScholar. Please contact us if we can make this document more accessible: pdxscholar@pdx.edu. 
AN ABSWACT OF THE THESIS OF

Norma $N$. degree in General Social Science.

Wate thesis presented: Oetober $31,1968$.

Title: An Analysis and Braluntion of the Arerican Electoral College.

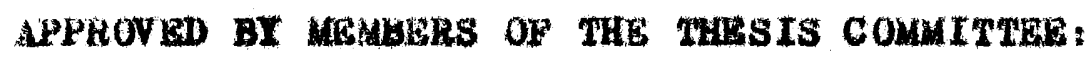
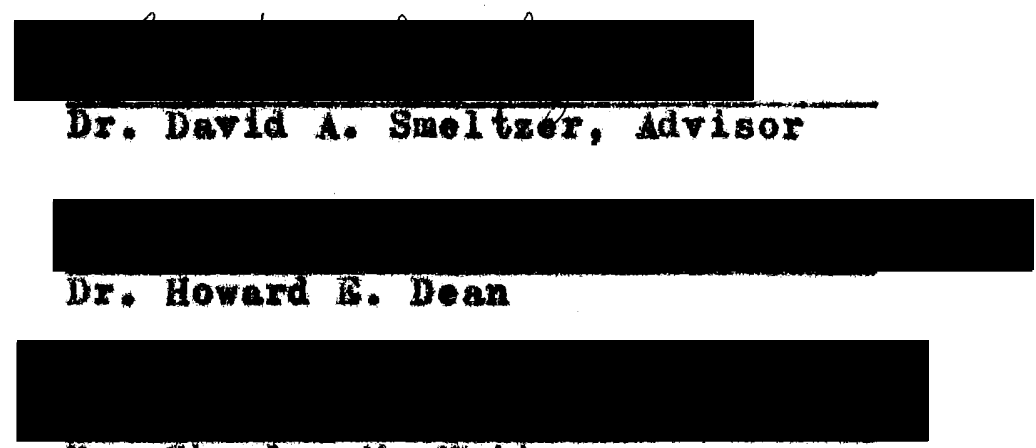

Dx. Chaxias M, White

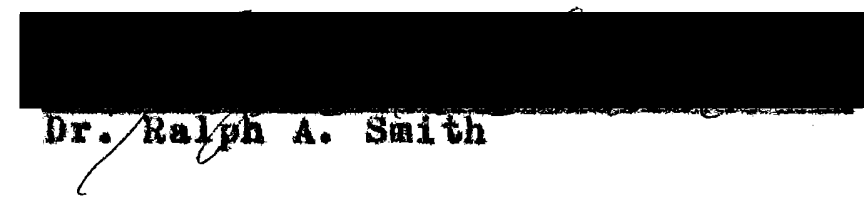

The Constitutional Convention of 1787 was greatly divided over the question of how to select the new nation's chief executive. The method finally adopted was a compromise between airect election and election by the national legislature and provided that individual states, as they saw fit, choose electors oqual to the total number of senators and Representatives. Wrom the beginning, most 
of the delegates considerad tik proposit awkand and irrational alwost to the polnt of aburalty, bat as they argued about it, they acas convinces that it was then the only plan which conld overcous the objections raised by o ther nethods.

The Conrantion had baroly axjourned, however, when

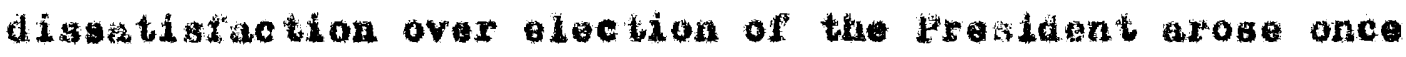

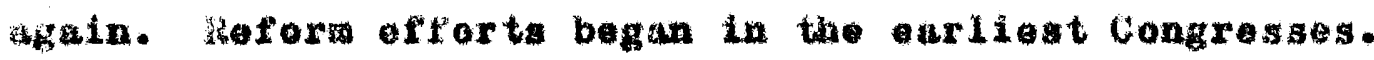
In the pest one hundrea and oighty yeara, woxe than 1000 amendibente-perhaps more then on any other subject-mave been introduced. These be divided into two distine

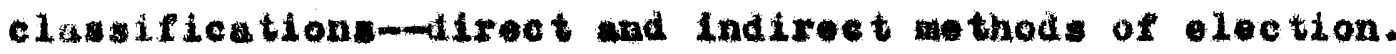

Frow the alatriet aystom propened in the oarly 19 th contury to the preportional aystem adraneed aost prowinontly atter Werld War II, oweh of the duliteot proposals hes bad ite dy and has been found wantige. It has becone clear that other lndireet methode of alection would merely turn in wow old probleme for wowe new ones. The preent ayatem, howover, is in corioue need of reforn. It dengers are roll documented. Pallure of electers to wote in aceordence ith the desire of the voters and the present allocation of alectoral votos makes it possible that under the present systen president can be lected who ls not the cholee of a wajority of the citizen. Furthermore, the present system proVides for an election in the House of Representatives if 
no candidate receives the necessary 270 electoral rotes. In a House election, each state casts one rote regardless of population. In viev of these factors, the electoral college is an undemocratic institution, an historic remant of a nation vastly different Irom the United States in the twontioth century.

Ihrough this nation's years of development, the Ideal of popular choice has become the most deeply Ingrained of our goveramental principles. Through our national experience we have learned that there is no safer or better, way to elect our public officials. No matter how wisely or foolighly the American people choose their President, he is atill their President. The electoral college should therefore be amonded to insure that the chief exceutive is the rolee of all 200 million Americans in practice as rell as in theory.

Only one type of preposed reform ean claim to give the people this reiee without oreating other problems in the election of the President. It is the direct popular vote proposal under whlch each eitizen's, vote, regardless of where it is east, would count equally with all other votes. The candidate receiving majority or plurality, as decided by Congress, would be the new president. A run-off eleotion vould replace election by the House of Hepresentatives if no candidate received the specified number of votes. 
No one, of course, can guarantee that direct election would never involve risks in the election of the President, but if one's premise is based upon an overriding consideration of democracy, the risk seems wor th taking. 


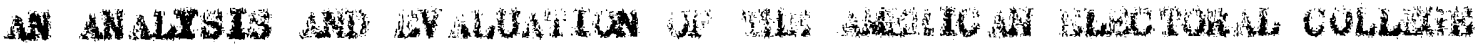

4

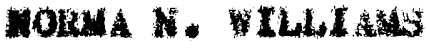

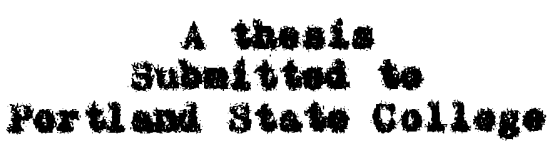

In partial fulftilment of roguirentente

Por the Degroe of

Mus ter of selones in Touching

do tobex, 1968

PORTLAND STATE COLLEGE

LIBRARY. 


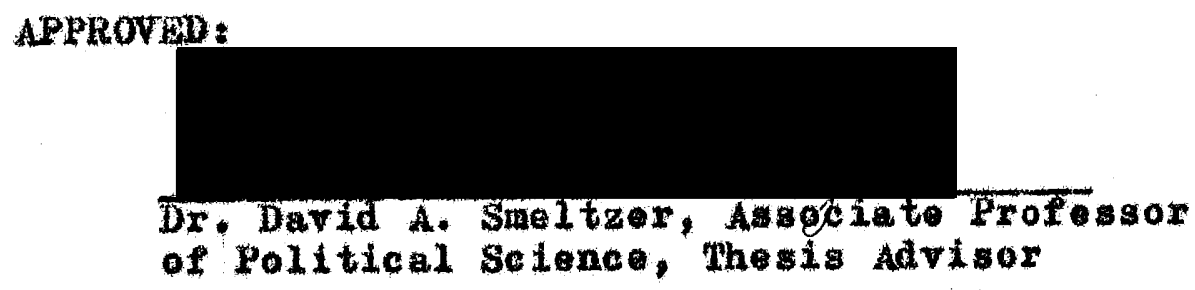

Dr. Howard is, Dean, Head, Dopartment of Polltical seience

Dr. Charies N. White, Professor of History, Division of soctal seience

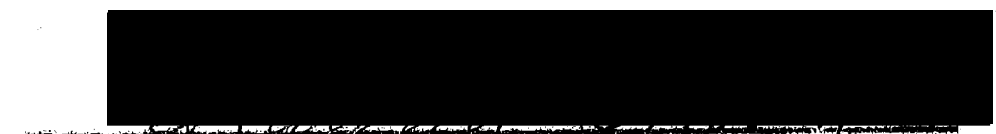

Dr. Talph AC Baith, Aseochate Frofossor of Education

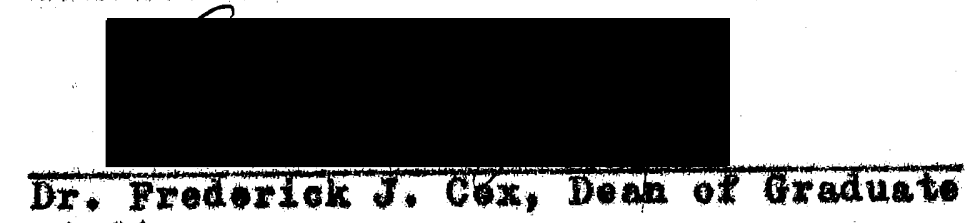

Studie:

Date thes1s prosented: 0etober 31, 1968

Typed by: Noxma N. WI11iams 
TART OF CONTENTS

CHAPTER

DACE

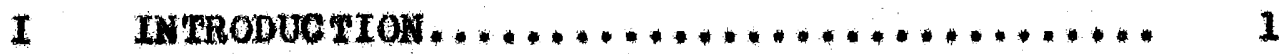

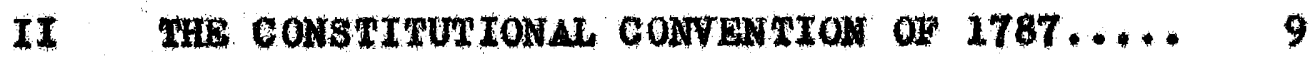

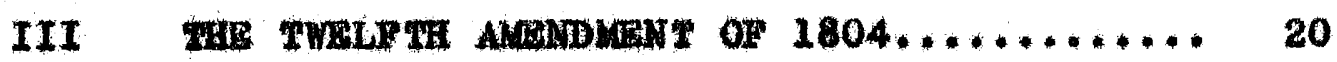

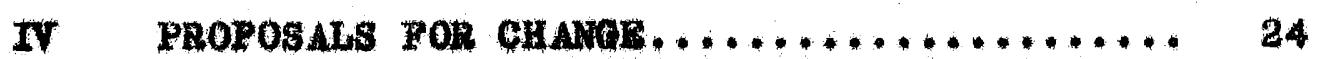

Whe Direet popular Vote..................24

The Automet16 systen.............. 45

The Dis triot Mo thod.....................49

The Proportlonal Plan............... 61

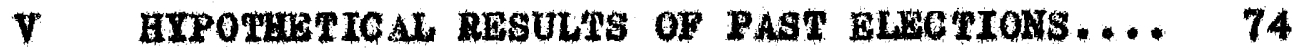

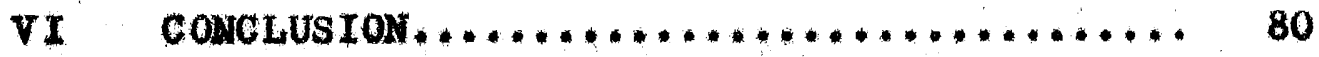

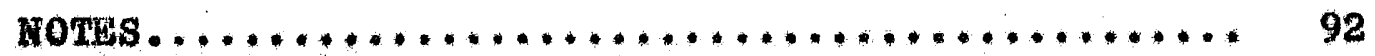

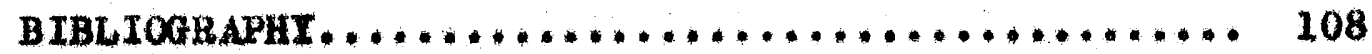




\section{LLB2 ON TAOHA}

Abla

Pas

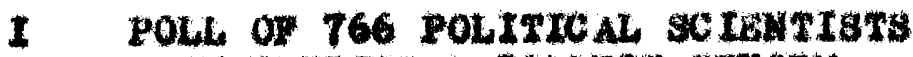

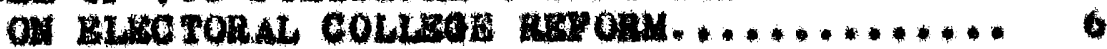

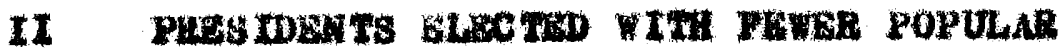

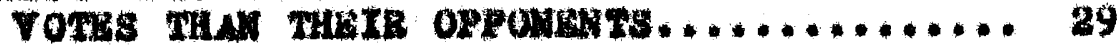

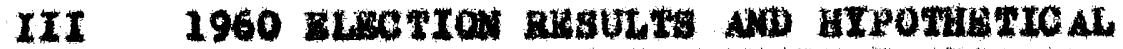

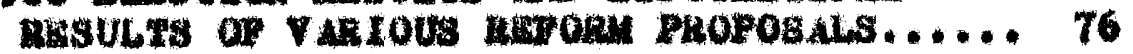

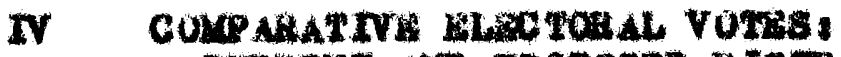

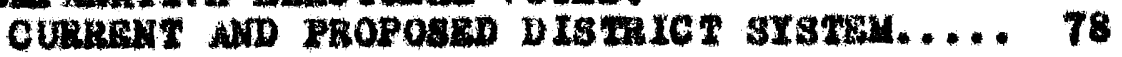

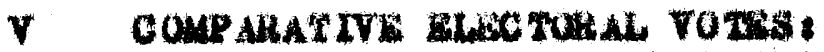

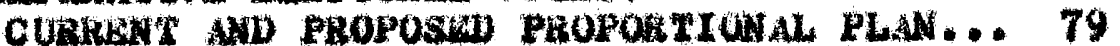




\section{CHAPTER I}

\section{INTEDHOC TOW}

The delegates to the Constitutional Convention in 1787 had barely roturned to their homes when dissatisfaction began to be roiecd regarding the method of electing the President and Vice-President of the United States. The pasalng yeare hare aggravated the defects and anomalies of the clectoral syatem. The election of at least three "atuerty" Presidents ("minority" in the sense that they received loss than helf of the nation's popular rotes), the consern orer porer advantages of 1axge and mell atates in proatdential eloctions, the teoling that bargaining porer of oplinter portios and preasure groupe Is inflated, the chanee of possible fraud in key stetes, and the peralbility of an election throm inte the Nouse of Reprewentatives, have been only sowe of the reacons for attempting to inotitute reform. The closeness of the 1960 election perticularly served to ineresse awaroness of the subject and to produce a whole new series of questions. The main question seoms to be whether as a protessed democratic nation we can eford to retaln this particular institution. could we today afford the repercussions-nationaliy and inter 
nationally-of electing a President who was not the choice of the poople? And has the nation perhaps outgrown 1 ts original thod of elocting its highest officials? In 1787 ours was a nation of $10 \mathrm{sa}$ than four million, 3.2 milion of whom were white adults and therefoxe eligiblo voters 1 we we then a ruyal economy now wo are an Industrial ome. Wo wore then a land of open paces, but today a nation of surglng metropolises. Our once stationary populace has mored on to "poripatetic pursuits" ${ }^{2}$ wo aro nation on whele and enjoy unirersal sutfrage. Whon the constitution was arted, education was haphazard at best; today we have troe publio oduention, and 111iteragy has been practically atamped out. Tho diatinet aristocreey in education and weal th from whioh our founders spreng has been replaced by doninant widlo class. Technology, particularly in the fleld of traneportation and commuteation, has altowed the nation beyond even the Wldest Imaginatione of thoae dologates progent In Philadelphia in 1787 .

The magnitude of controverey surrounding the electoral ellege nay perhape beet be $112 u s t r a t e d$ by the ract that over one thoumand amenamentis on the subject have been propesed in the past ninety Congresees. 3 The - loctoral college way laded be deseribed as anique Institution. As one author deseriboe, the "collega" consistis of 538 mombers (the same roprosentation ao both 
houses of Congress, plus three electora frow the District of Colunbia;) it has no specific location and no permanent existence as a continuous body; and it has never assembled as a whole. 4 surveys indicato that it is the least understood and the most mieunderstood of our political institutlons. 5

Like tho Britioh wonereh, who roigns but does not rule, the lectoral college votes but does not decide-to the perplexity of eng generation of students of imeriean Governaent, 6

The anthor of the ebove pasage, Robert $\mathrm{G}$. Dixin, asserts in the vestern Politien ouerterly that aore cumbersome procedure could herdiy be Imagined or conselougly designed for eloeting the Prosident and Vice-president of the United Statos, ${ }^{7}$ Ho continues:

- . the electoral proeess has been anonded into moninglest anchronisn and preserved by the Inertio surrounding all thinge Constitutional-one more instance of Burke's obseryation that constitutions are not made, but grow.

The American Bar Asociation, one organization attempting to effoct change, has condomed the electorel college as "archale, undemocratie, complex, indirect, and dangerous." 9

other witers on the subject have been even less kind. The rashington Post has acknowledged the electoral college as "a crude and burbling mechanisa in modern politics" whose electors are tolerated only because they are "puppets or dumies" who merely record the wishes of 
their parties at the polls. 10 The Novernber, 1967, is sue of Reader's Digest warned its millions of readers that the present "winner-take-all" practice of the olectoral college is "totalitarian"--the "taproot from which wany political evils grow." 11 The Mer Republis has labeled the lectoral college a "huapty-dumpty" ingtitution, "destgned for a totally different oge."12 The Nov York Iines, e Irequent commontstor on tho oubject, has called the eleteral college "el11y" and "dengerous". The Iimes has also referred to two unnoticed stick of dynarat Iyling around in the U.8. Constitution."13 (By this they mean the required 270 vote leotoral majority required for election and what they consider the Inoquality of an aleotion in the Nouse of Representatives.) A Times editorial once labeled eloctoral rotes a "entrance ticketa" to the Houge of Representetives "madhouse". 14 When the oditorial appeared in July of 1967, its author was fearful of the necessity of a louse vote to decide the outeome of the 1968 presidential election. He incorrectly toresaw a Johnson-Huaphrey/Rockefeller-Reagan contest in which neither would receive the necessary 270 electoral mejority. He further predicted that third party candidates Wallace and Thurmond might carry as nany as six tates and capture 53 electoral votes, 15 and he feared that the wor candidates aight then bo roreed to make sizeable concessions to the third party in exchange 
for valuable electoral votes. Also, he pointed out that there rould be no guarante that a House election would represent the will of the poople and that under present provielons where the Senate would choose the Vle-President, it might be possible to elect a Prosident and a vicePresident from differing polltical parties.

Refora of the olectoral college has been the topic of numerous piblie opinton polls. In the fall of 1948 , the Americen Institute of Publie Opinion reported that 58 per cent of the Ameriean people polled favored changing the wethod of olecting the President ao that oach candidate would recelve the ane proportion of the electoral votes of eseh state that he recelred in the popular rote. Pifteen per ent of these polled farored maintaining the prement arsten, wh11e 27 per cont expressed no opinion. 16 In 1960, Gallup Poll showed that 57 per cent of the people polled farered the Lodge-foasett proportional rote anendment while 28 par cent opposed it. 17 In April of 1960, Gallup reported that 50 per cent of the peoplo polled fevored a change, 28 per cent opposed, and 22 per cent expressed no opinion. 18 a poll taken among 766 politioal seientiate by the senate suboomittec on Constitutional Amendments pursuant to its 1961 hearings in the 87 th Congreas received 254 answers which are revealed in Table I on the following page. 
TABLE I

POLL OF 766 POLTTICAL BCIENTISTS

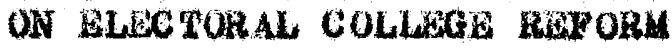

\begin{tabular}{|c|c|c|}
\hline & $\begin{array}{l}\text { Por cent } \\
\text { in favor } \\
\end{array}$ & $\begin{array}{l}\text { per cent } \\
\text { opposed }\end{array}$ \\
\hline $\begin{array}{l}\text { Changing the method of } \\
\text { electing the President }\end{array}$ & 90.6 & 9.4 \\
\hline Abolishing lector: & 71.7 & $24 \cdot 4$ \\
\hline $\begin{array}{l}\text { Retaining present electoral } \\
\text { strengths of the atetes }\end{array}$ & 60.7 & 33.4 \\
\hline Direct national election & 34.2 & 63.0 \\
\hline Proportional yatem & 46.9 & 48.8 \\
\hline District system & 16.2 & 78.3 \\
\hline $\begin{array}{l}\text { Changing ysten of contingent } \\
\text { alection by the Louse }\end{array}$ & 55.9 & 37.8 \\
\hline $\begin{array}{c}\text { Contingent lection by joint } \\
\text { meeting of House/senate }\end{array}$ & 51.2 & $27 \cdot 2$ \\
\hline
\end{tabular}

A 1966 Gallup Poll revealed 63 per oent of the Amerioan people polled that year farored alimination of the electexal college and abstitution of the direct popular vote, 20

In 1966, Senator guent1n 1. Buxdick of Noxth Dakota polled 2200 atete legislators and found 59 per cent of those replying in favor of direot populax vote. 21 in the same yoar, a sampling of hi: North Dakota constituents also found 59 per oent in faver of alreet popular election with only 9.7 per eent in faror of the present system. 22 A similar 1967 poll in Oregon by First Congressional 
District Representative Hendel1 Wyat indicated 76.1 per cent in favor of the direct popular vote mothod and 14.8 per cent opposed.23

In a merbership referendum during December, 1965, and January, 1966, the local, state, and regional chambers of Comuerce and their associated trade and professional organizations roted 91.5 per cont in favor of electoral college reform, either the nationwide popular vote proposal or the distriet thod. 24 similarly, 91 per cont of member: surveyed in 1967 by the National Small Business Association favored direct popular election. 25

While no seholax would adrocate electoral reform on the basia of evidence gathered from polla alone, it should be steted thet considering the history of electoral reform, passage of any proposed amondment in the future will und oubtedly depend on broad publie aupport. Enough attention has been directed toward the undemocratic. aspects of our presidential election process that even those who fear no real potentiel dangers from the present system would want to be guaranteed that any change is truly a demoeratie one.

In the following pages this paper will attempt to analyze and oraluate the American alectoral college. It will begin by discussing the Constitutional Convention of 1787-what really happened there and what the founders really intended, as we can ascertain through the conven- 
tion records. It will then discuss briefly the Twelf th Anendment passed and ratified in 1804-the only substantial constitutional change made in the method of presidential election. The paper will then attempt to analyze and compare the various changes which have been proposed over the years. Emphasis will be given to the reasons why none of the proposed changes was able to generate enough interest to be acted upon by the required two-thirds of Congress. Aftor a fow examples showing hypothetical results of past elections under the rarious proposals, the paper vill conclude by considering the present political dimposition toward the eloctoral college and what changes should be expected in the future. 
IHE CONSTITUTIONAL CONVONTION

Alhough there was little difficulty in agreeing that the President and Vice-President should be elected officials, the Constitutional Convention of 1787 disagread widely on the method of election. Speaking on the floor of the convention, Pennaylvania delegate James Wilson said, "The subject has greetly dirided this house. . . It is in truth the most diffioult of all on which we have had to deciale $n^{1}$

At least five distinotive proposels for selecting the President were made at the Constitutional Convention: (1) direet pepulax election, (2) election by congress, (3) lection by the stato legialatures, (4) election by Intermediate electors, and (5) appointment by 10t. Each proposal had Vigorous adherent and opponents. Of these proposal, those ineorporating direet popular election and election by the national legielature receired the most debate.

Woat roeal anong the delegaten favoring a direct popular vote were W1lson, Gouverneur Morris, and Benjamin Franklin of Penngylvania, and John Dickinson of Delaware. They maintained that direct popular election of officials 
in New York and Massachusetts had shown it a convenient and suecessful mode. Arguing with proponents of state election, who feared parochial interests would produce inconclusive results, the Wilson Paction pointed out that the best inen would be known to the people if they were known to their state legislatures. ${ }^{2}$ But while many of the delegates approved the direct vote in principle, many, such as George Mason of Virginia, thought it impracticable. ${ }^{3}$ depresentetive Eldrige Gerry of Massachusetts said he liked the principle but wanted the poople to feel the nocessity of 1 t. 4 Wilson, who presented the idea to the convention on June 1 , admitted that he was almost unwiling to propose it," . . apprehensive that it might appear chimerical." 5 As debate continued, direct election of the Prosident began to lose ground. Somo delegates worried that largo northorn states such as Massachusetts and Ponnsylvania. uight have an advantage as compared with Virginia whose slaves had no suffrage. Beflecting this montiment, Hugh Nilliamson of Yorth Garollas atated, "The people will be sure to vote for some man in their own state, and the largest state will be sure to sueceed. . ." 6 Colonel Mason asserted that leaving the election of the President to the people would be an unatural as referring "a trial of colors to a blind man." 7 He was joined by Gerxy who believed that the evils of the time flowed frow "the excess of democracy" and that the people were "dupes of protended 
patxiota." 8 "The people at large," said Roger Sherman of Connecticut, "could never be sufficiently informed to make the proper choice." 9

Adrocates of election by the national legislature cautioned against "the well-meaning, but uninformed poople," a phrase once used by Thomes Jefferson. 10 This method, it was argued, would be little better than the quickly oldifinated proposal for appointment of the President by 10t. Why not adopt plan whereby the poople, easily distinguiahing ameng their ow nelghbore, would elect nembers to the House of Representatives, or to the state legislatures, which would in turn leet Senators who would appolnt the executire? ${ }^{11}$ Mason, however, Peared two evils In the system: "false complaisumee on the side of the logislature towards unfit charactors," and "tomptation on the stde of the exocutive to intrigue with the legislature for a reappointment." 12 others agreed that this method of election would confliet with the principle of executive Independence; the President would lose the role of proteotor against legislative tyranny. ${ }^{13}$ According to Mad1son:

A dependence of the Bxecutive on the Leglslative would render it the executor as well as the maker of laws; and then, according to the observation of Montesquieu, tyrannical law may be made that they may be executed in a tyrannical menner. 14

Some delegates hoped to avert these difficulties with a suggestion that the president be named by the national 
legislature but that he be ineligible for reappointment and thus free from future temptations. In this rein, a longer presidential tera was favored: seven years. But the majority found this suggestion repugnant in that it right create an undesirable rotation and form "a political school in which we were always governed by the seholars and not by the maters."15 A fow delegates feared that the President might get too old before the end of a seven year term and asked their fellow delegates to "eonsider. . the first megistrate saddled on the country]. . should it be found on trial that he did not possess the qualifications ascribed to him, or should he lose them after his appointment." 16 Roger Sherman adriaed, "He who has proved hinself to be most eft for an offloe ought not to be excluded by the constitution from holding $1 t ., 17$ In addition, Morris bellered thet President ineligible for re-election aight fix his sights on pesition in the logislature, consequently performing peorly in the last years of his presidener. 28

An alternative to lection of the Prosident either by direct popular vote ox by the national legisleture was the axggestion that the executive be chosen by the state legislatures. It was argued that this rould preserve hermony between the nation and state governments. Under this plan the state gorernments would elect the Senate and House mombers as well as the executive. Each state rould 
be allotted a certain number of votes "according to some equitable ratio,"19 and electors rould cast the votes. This plan would conciliate state partisans who wore already professing alarm that a new constitution would supersede state authority. The plan ras quickly eliminated, however, with the argument that the states would look out for themselves rather than national interests and that the executive might be rendered subservient to the states. Furthermore, it ras felt that the states would act as rivals and therefore undermine or oppose the national government. It was pointed out that the states then in exiatence had, in fact, show lack of harmony with federal proposali. 20 Hy late July, Madison had "convortod" from the group origlnally faroring alection by the national legigleture and remarked that only two options remainod: - lectors ehosen by the peeple or lanediate appointent by the poople 21

Voting on Auguet 24, the delegates dofeated both the elector plan $(6-5)$ and the direct election proposal $(9-2) .22$ Pre day later, on Auguet 31 , the problem was referred to a "arand Comittee" for atudy. Selected by ballot, this comitteo was comprised of one member from each state represented. 23 of the leren mombers, six wero known to faror difect lection (Gourerneur Morris, Madison, Dlckingon, Rufus King of Massachusetts, Daniel Carroll of Maryland, and Abraham Baldwin of Coorgia). Only sherman 
of Connecticut was sald to be unreservedly opposed. 24 It is therefore surprising to note that when the "Grand Committoe" reported back to the convention on september 4, 1787, it did not recomend election of the presidest by direct rote of the people. Also rejected was election by the national legislature, for it was felt that this proposal wa inconsistent with the recomendation for a four year presidential term, at the end of which the President would be eligible for remelection. 25

What the "Grand Committee" did recomend was that each state eppoint, es their legislature directed, a number of elector equal to their total number of Senators and mombers in the House of Representatives. ${ }^{26}$, This modification of popular election had been altered in detail to take care of the diffieulties of Negro representation and tate favoritism. The chosen electors were to meet in their respective atede and rote for tro persons for President. The provision that one of these must not be an inhabitant of that ata was designed to remove stalemates which wight rosult from backing "favorite son" candidates. The sealed eloctoral rotes were to be sent to the Prosideat of the Senate for counting. If no candidate receired a majority, the senate would choose one from the top two of three whose votes comprised a majority, or if necessary from the fire highest candidates. 27 As fur ther safeguards, it was agreed that no nember of the 
national logislature and no United States officer could serve as an elector; the number of votes required for election must equal a majority of the actual electors appointed; the electors' sealed certificates were to be counted in the presence of both the House and Senate; and the Senate was to ballot "immodiatoly" if it wore forced to choose the prealdent. 88

When the "Grand Comittee" report was brought to the convention floor for debate, it wes attacked mainly on one groand: that the senate was the improper body to make the orentual selection. Many delegates foared that olectors would seldom come to deflnitive cholee, that they would make the eandidates but the Senate would make the President. Colonel Meson estimated that nineteon times out of twenty the President would be chosen by the Senate. 29 In his words, the president would be "the minion of the senate." 30 therefore, at the suggestion of sherman, election by the House of Ropresentatives was substituted for olection by the senate; and to maintain the equality of suffrage enjoyed by the several states in the senate, the rote of the House was to be taken by states and not by individuals-each ate having one vote. 31

on September 12, the Iinal plan was sent to the Committee on style and Arrangoment, which made no substantiel change, and on september 17 the entire constitution was agreed to by unmimous consent of the states 
present. 32 New York delegate Alexander Hamilton, writing In the 68 th Federalist, voiced the opinion that this manner of electing the President "if it be not perfect, is at least excellent." 33

In any discussion of the Constitutional Convention, the question invariably arises just what the founders intended whon they atablished the electoral college method of selecting the President. Theix actions are frequently attacked as undemocratic, as representing a contenpt toward the comon man. Was it the delegates' intention that electors should use their own will without the slightost control erom the people, and did they perhaps intend to exclude the people from all participation in election of the nation's executive?

Apparently some chargea that the nothod of selecting the President was a "conspireey" against the common peoplo had begun to be heard long before the convention adjourned in september, 1787. During the conrention, more than one dolegate spoke of the goal to protect the executire from radical elements in socioty, particularly those which sometimes expressed themselves through the modium of popular -lection. The desire to prevent fuetions (parties and pressure groups) frow playing a major role in the selection of the President was also roiced in the convention. A general distrust of political parties characterized that era and is nowhere more clesrly expressed than by George 
Washington in his First Inaugural Address. 34

Princeton Professor Lucius ilmerding, until recently the only author of a comprehensive book on the electoral college and a person who on a number of occasions offered testimony on the subject before the Senate Judiciary Committee, asserts that it is the Pashion nowadays, and has been for over a century, to answer "conspirecy" charges in the affrmative. Wilmerding contends, however, that a majority of the founders, as we know them through the convention recorda, had no such intentions. 35 Robert Lldon Brown agrees ith this position in A ReInterpretation of the Formation of the Anerican Constitution:
We have tended to think of the found lng fathers as men coldly motivated by the $1 \mathrm{r}$ coononie Interests. . but wo find Madisom, Virginia planter, believing that comereial and manu- faeturing Intereats had quel claime to protection and partiolpation 1a gevernment, and if the show- down oror came, property rights veyld have to be sacificed to univoral uffrage. 36

Nathaniel Gerhan, alegate to the Constitutional Convention fron Maswachusetts, lelt compelled to sate that in his opinion there was wo evidence in the convention debates to suppert the otatement that there was a mass of disfranchised men." 37 W111am Paterson, New Jorsey deleGate, adrised that "the demooratick spirit" ran high. 38 In the Virginia retifying corvention, Madison was careful to explain that the Prosident was to be the choice of 
the people. 39 He fur ther explained that the method of election was the result of a compromise between the larger and smaller states, giving to the latter the adrantage of selecting the President from the candidates ". "In consideration of the adrantage possessed by the former in selecting the candidates from the people." 40 Edmund Randolph al oo defended the lectoral plan in Virginia and aphasiged the Importane of lectors Helected by the people at large " 41 In the 68 th Lederallet. Hanilton repeatediy stated that the appelntment of the President was to be referred in the first inatanes to un "ianediate act of the people, 42 eren though in the 45 th pederallst he conceded that eleotex might conatitutionally be chosen by ste logialatures, a plan taken $10 x$ granted in 1789 by Bldridge Gerry. 43 vimen told the Penasylvania ratifying convention that the cholec of the President was brought as nearly hom to the people as was practical, otating that the poople mretain supreme power. " by representation." 44 As Wilmerding concludes, ". wo mut look upon them [electorg7 as a modiun for aseertaining the public will." 45

There appears to hare been little criticism of the electoral method during the debater in the various state ratifying conventions. As Alexander Haril ton noted:

The mode of appointment of the Chi Magistrate of the United $S$ tates is almost the only paxt of the system of aay consequence which has seaped. without severe censure, or which has received the ilighest mark of approbation Irom its opponents. 46 
Brown suggests that the silence of the delegates on this matter when they returned to their respective states may have stemed from embarrassment. ${ }^{47}$ It is known that some years after the Constitutional Convention, Senator illiam Plumer of New Henpshire told his colloagues that he had been "repeatedly asaured [5y several of the delegateg] that this subject had ombarrased thom more then any other" and that the method of electing the prosident was "less exceptional" than other prinoiples derisod at the convention. 48 Forrest MeDonald, cuthox of $\mathrm{g}$ Pluribus Unum: The Formation of the Ameriean Republic, stroagly disagrees, howerer. He has recorded that the electeral college system was the only real governmental innovation devised by the convention. 49

It was an awkward schome, 1rretional almost to the point of absurdity, and it was so greeted by most of the delegetes; and yot as they argued about 1t, it beceme inereasingly clear that this was a system that would overcome every objection thet had been raised againwt every other method. 50

Above all, it must be remembered that the olectoral college system of choosing the president was a political expedient arrived at after all other proposals had encountered a great anount of political opposition. Janes Madison later admitted that the delegates' fatigue after a "long, hot summer" of negotiations in Philadelphia had a lot to do with the quick adoption of the system "with virtually no substantive debate. ${ }^{51}$ 


\section{CHAPTER III}

\section{THE TWELFTH AMENDMANT}

Exeept for one ninor change, brought about by the passage of the Twelf th Amendment in 1804, the method of - lecting the Fresident has rementined unchanged during the one hundred eighty years since the Constitutional Conrention. The Trolfth Amendment changed Article II of the constitution to provide that lectors cast tro ballots, as distinguighed from one with tre names. One ballot is to deslgnate the person voted for as Preaident, the other the person roted fer as Vice-president. It no person receives a majority of the total rotes of appelnted electors, the House (In a tate by state rote) immediately chooses the President from the three peraen hering the bighest numbers of electorel votes (redueed from the prevous five persons). The anendment further provides that the person having the createst number of lectorel rotes for VicePresident, if that number be a mafority (chenged from pluxality), becomes the Vlec-President. If no one qualifies under this provision, Senate majority selects the V1e-President frow the top tro eandidates. A quorum for this purpose mat consist of two-thirds of the whole number of Senetors. I The amendment contemplates the old, 
or "lame duck", House of Representatives selecting the President.

The Iwelfth Amendment may be viewed as a direct rosult of the presidential election of 1800 . Hy the end of Washington's flrst term, party pirit had reachod a degree of bitterness not surpassed for a contury. A deep, twoway cloarage of thought began to breed diasater for the -lectoral college aystem. Conflict orer the nature and power of the federal government pitted ageinst each other such wen as Alexander Hamilton, John Adams, and Thomas Jefforson. Flootion issues became subordinsted to the merits of the candidates who made the issues. Eloctors became mere tools for the agencies seleoting them. The function of elocters as intended by the Conatitutional Convention was eliminated, and from that point on electors alwost nover exercloed ladependent judgment. ${ }^{2}$ party spirit, non-existent in 1787 , created an electoral college in practice much different from that in theory. In the words of one suthor, the electoral college "died before it was mature." ${ }^{3}$ By 1796 political parties were assuming the reaponsibility of nominating electors, and there was a popular leeling that electors were morally obligated to rote for the national candidates of the party. ${ }^{4}$ In a sense, then, the Twelfth Anendment serred to confirm parties.

In the election of 1800 , the Republican electors 
roted for Thomas Jefferson and Aaron Burx. They intended that Jefferson be prosident and Burr Vice-President, but Burr received as many electoral rotes as Jefferson since, under the origlnal method, there was no separate ballot for Vice-President. ThIrty-ilve roting sessions in one reok in the House of hepresentatires were noesesary to decide the election. 5 Fad the lectors roted accerding to their om convietions, Burr would probably never hare been a real contonder, but instead the oloctors roted for the ticket.

It must be emphasised that the unit rule ("winnertake-al1") mothod of counting electoral votes is not part of the Constitution. States are ere to adopt other methods of aelecting their presidential electore, but considerations of political porer have entablished the unit rule as a general practice Tor wore than a contury. Defore 1804 , a mejority of atatos chose electors from districts, in a manner siailar to election of Congreas. Then it soon became apparent, howerer, that a state which could delirer its entire electoral vote was politiealiy more porerful than one whose rote was split, logislatures began to drop the district system in state after state. After 1804, states could not afford to return to the distriet system, and from that time on little attontion was pald to electors. 6 James Medison, writing to a friend in 1823, said that the district method of choosing electors "was mostly, if not oxclusively, in viev when the Constitution was framed and 
adopted," but he added that it was exchanged for the general ticket because "it was the only oxpedient for baffing the policy of the particular states which have set the example." 7 He and Jefferson, in fact, influenced Virginie to switeh from the distriet method to the general ticket in 1800 so that their party might secure all its electors. 8 The eleetion of 1824 insured the death of the diatriet aystem in all atetes. In that election, John

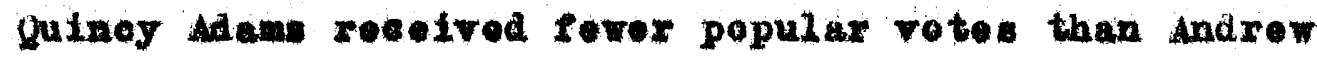
Jackson, but diams won the prealdonoy won the election went to the House.? 


\section{CHAPTHR IV}

PROPOSALS FOR CHANCE

Since the Constitutional Convention in 1787 , approximately one thousand amendments hare been introduced to ohange the wethod of electing the President and VicePresident of the United States. Basically, however, the amendments fall into two catogories: (1) complete abolition of the provent systen and (2) alteration of the present system. In the e1rat category is the direct popular vote; in the secoad, the autometie, distriet, and proportional vote plane. Bech will be disousaed in detail in the followlag portion of this peper.

\section{DIRBCE POPULAR VOTE PROYOSALS}

As orident from the recerds of the Constitutional Convention, direct popular election of the President was from the beglnatag serieus proposal but lost in the compromise already diecussed in Chapter II. The direct vote wethod would simply award the presidency to the candidate receiving a majority or plarality, as may be provided, of the nationwide popular reto without regaxd to state boundaries and excluding any electoral rote conslderations. Direct amendments proposed prior to the middle of this 
century generally favored election by a plurality, more recent resolutions by majority, although the most recent dotailed proposal from a special study committee of the American Bar Association again farors a plurality. The eirst plen for direct popular election was of the plurnlity type and was introduced into the House of Representatives in 1826 by William MeManus of Mew York." sinee the MoManus proposal, at least one hundred similar ones have been introduced into the House and senate. Interest in electoral reform soemed to diminish after the defeat of several amendments in the 1950's but was rekindled when the 87 th Congress convoned in 1961-apparently stimulated by the oloseness of the 1960 election between John F. Konnedy and Richard M. Nixon. Although Nixon lost that eleotion by 136 electoral votes, there was only e fraction of one per cent difference in the popular rote totels. 2

S.J. Res. 1 in both the 87 th and 88 th Congresses and S.J. Res. 6 in the 90 th Congress, all sponsored by Maine's Sonator Margaret Chase Smith, would have completely abolished the electoral college system. Under this plan, a stato's popular vote tally for each candidate would be sent to the Secretary of State for opening and counting, and the person raceiving mejority of the total votes would be President. ${ }^{3}$ Congress would be authorized to legislate in respect to possible ties in either the 
primary or general election. Voters in each state rould be required to hare the same qualifications requisite for election to the nost numerous branch of the state legisIature, and Congress would be authorized to alter any state regulations on the place and manner of holding the primary and general elections. 4

In the 88 th Congress, S.J. Res. 73, introdueed by Wew Iork Senator Kenneth B. Keating, called for a direct national vote for President and Vice-President running together on single tiekets with the election awarded to any ticket with plurelity. This anendment rould also hare mored the Inengural day of the now Proaident to Decomber 1 from January 20.5

Direct election proposals in the 90 th Congress drew heavy aupport from the Ameriean Dar Association's Commission on Blectoral College Reform. In oarly 1966, the Bar Association' Louse of Delegates authorized a one year study of the subject. sugesstions from the Fobruery, 1967, report wero ineexporeted into S.J. Res. 2 sponsored by Indlena's Sonctor Birch Bayh and 19 others.

s.J. Les. 2 rould have provided for election of the Prosident by a nationwide direct popular rote of at loast 40 per cent and would have called for a netional run-ofe between the top two candiates if no one recelved 40 per ent of the rotes on the first ballot. The Anerican Bar Association' Commission on Electoral College Reform con- 
cluded that more than a 40 per cent vote was neither Peasible nor necessary since election statistics show that 12 U.S. Presidents in 14 elections received less then 50 pex cent of the popular vote. 6 S.J. hes. 2 would have also required thet the President and Vice-president be roted for jointly, and Congress would hore been empowered to deteraine the dates for the orfginal and/or run-off, which would have boen uniform throughout the mation. The places and manner of the lection and the nanes on the ballot were to be preceribed by each state legislature, and voters in the states rould have been axpected to hore the wave qualifications as required when roting for sonatore and Bepresentatives.7

Antielpating posalble Congreasional ation on uniform age and residenee requiremente for rotine, s.J. Hes. 2 recomanded that should such ation oceur, states be perint ted to continue to adopt their own residence requirewonts, possibly less atriet than the national. 8 This would ald new residents or ones whe hare mored and hare not yet become full residents of anothor atate.

In addition, the American Bar Association report recomended that appropriate provisions be made to corer the possible death of a candidato. It mentioned no specific proposals but suggested that Congress work out nocessary details. 9 Like almilar proposals in past years, howover, Congress adjourned before S.J. Res. 2 could be brought to the floor for a rota. 
Arguments in Pavor of pirect glection

Those in favor of direct election, including the American Bar Association, argue that the results of a direct election would gire a more accurate picture of relative party strength than do electoral vote results, When a party with the most popular rotes in a state wins all the lectoral rotes in that state, the strength of the winner tends to be needlesaly exaggerated. "The system creates 'landsidea'."10 for Instence, in 1952 Eisenhower, with about 55 per cent of the total popular rote, won over 83 per cent of the nation's lectoral votes; in 1936 Reoserelt receired 60 per cent of the popular rote, but 98 per cent of the olectoral vote. 11 In fact, in oleven Instances ine 1824, Including the 1948 and 1960 elections, the present systen has given a nority of the electoral votes to candiate with only plurality of the popular vote. 12 one queation which has yet to be resolved anong those who favor alrect vote lis the iaportance and foasibility of having a President elected by a major1ty. As already noted, the American Bar Association Pavors a 40 per cent plurality be required for election and feels that requiring more than that smount would introdue the undemocratie prospect of a House election where states recelve equal rotea. Others, such callfornia's senator Thoma H. Kuehel, believe that national strength depends upon the solidarity of the American people behind a Presi- 
dent wo is elearly a majority farorite. 13

Adrocates of direct election proposals are quick to point out that three Presidents actually trailed their opponents in popular rotes received. If the winning party carries many states by bare pluralities or narrow sajorities while the opposing party acquires most of its rotes by wide margins, the candidate with a mority of popular rotes could win a mority of the total electoral votes. Statistles concerning the "winners" of the 1824, 1876, and 1888 elections are shom in the following table, 14

\section{TABLS II}

PRES TDENTS ELEC TED WITE FEUER PEPULAR VOTES THAY THEIR OPPOMBMTS

Ieer

1824

1876

1888 nleoted

\section{Adame}

Hayos

Harrison $47.86 \%$
Chief opponent

Jeakson $43.13 \%$

Tilden $50.99 \%$

cloveland $48.66 \%$

A erequent argument for direct eloation is that it would be afmplor for voters to understand than the present complex aratem. Vriting in the Lew Repablic, Noal Peirce, politieal oditor of the Congrenslenal puarterly, states that abollahing the electoral college would simply confirm a direct relationship of the ameriean people to their Prenident that most anericans think exists anyway, ${ }^{15}$ In fact, in recent years there has been a trend among states to drop electors' names from ate ballots, providing in- 
stead a square beside the names of the candidates-each mark counting as a vote for loctors of that party on file with the reapective secretaries of state. 16

"Presidential U.S.A. and Congressional U.S.A. are, electorally speaking, two different countries within one boundary, ${ }^{17}$ say supporters of direct election. Since adoption of the 17 th inordwent in 1913, the President and V1ee-President renatin the only eleetive officials in the United states not chosen alrectly by the people. 18

Adreeates of direct lection alwo bellere that the aystom would invigorate the two-party systeal, particularly in sections of the combry where one party is now so firmly ontronohed that other parties have no incentive to try to win. "Instoad of Ropublican votes in certain Southern statos bolag relatively useloss to the national party, they would be added to the national total."19 The same would be true for Demoeratic rotea in hearily Republican states.

In sifting through the arguments used to support diroct popular rote, it becomea apparent that direct rote amendments are supported by varfous groups for several different ressons, sone of which are contradictory. This is bost illustrated in the coneorn over power advantages of large and small atates.

Senator John B. Pastore of Rhode Island is among supporters of direct election who would like to see the 1mportance of large, doubtful, so-called "pivotal" states 
diminished. It has been said that a vote counts more in a "close" state than in a "sure" state, that a fow voters in key states pay possess the power to elect or defeat their candidates. 20 In a state where the result is more or less preordained, the possibility of a similar group of voters swinging an election is almost non-existent. A direct -lection, adrocates feel, would almost certainly encourage more people to vote. Only 60.5 per eent of the 11 gible roters throughout the United states exercised their franchlse in the 1964 olection and only 63.8 per cent in the closer 1960 election. 21

Many feel that adoption of the direet rote would allow campaigning to be more evonly distributed throughout the netion and that candidates could seok out "rich sources" of votes outside the lerge motropolitan areas within large otates. 22 chey further feel that direct election would reduce the premium now placed on ohoosing candidates from the large koy tatos. It is sald that presidential aspirants from "pirotal" stutes have disproportionate chance of roeeiving their partys' nomination, for by choosing candidate from one of the large otatos, a party may possibly attract the fow rotes it needs to carry tho state. In the past fifty years both major parties have generally limited presidential nominations to mon from the ight largest states. Bxceptions include Land on of Kansas in 1936, John Davis of Vest Virginfe (though a Wall stroet lawyer) in 
1924, Truman of Missouri (who was already President when nominated) in 1948, Goldwater of Arluona in 1964, and Humphrey of Minnesota in 1968.23

The ldea that large states monopolize presidential nominations and roduce residents of small states to "gecona cless citizenahip" led the stute of Delaware to legal action In early 1964. Finaneed by the Small Business Association, Delaware aamed the state of Her Iork as ohief defondent. ${ }^{24}$ Delaware's Attorney-Generel Darld P. Duokeon argued that the unlt rete or "winner-take-al1" aysten deprires ninority roters (often as much as 49 per aent of atate) of an effectire rolee in an olection and that the rotera instead we their rotes applied to the opposing candidate. Buckson called "arbitrary aldappropriation of ainority roting strength" a deprivation of the 14th Anondment guarante of equal protection under the law. ${ }^{25}$ CLting the $1963 \mathrm{U.S}$. Suprene Court deciolon whioh struek down Georgie's "little clectoral college", 26 Deleware sought to have the unit rote deelared une onetitutional. Delavare was eneouraged by judielal comment in the Gray ceve that the ideology of the loctorel college Itrelf belongs to mbrgone day". 27 Delarare we jolned in the effort by ton other atates (Pennsylvania, Oklahome, Kentucky, Iowa, North and South Dakota, Arkansas, Wyoming, Florida, and Utah), but the controveray ended quickly in Oetober of 1966 when the court refused to hear the ease 28 
On the other hand, some direct lection supporters beliere that small states exercise an unfair advantage orer large states in that small states have more electors relative to population and therefore fower voters who control the electoral votes. As Harry Louis Seldon comented in an article in American Heritage, "The electoral college is based on a mematical inequality. ${ }^{29}$ For example, a review of the 1960 census eigures indieates that Alaska's three electors repreant only 21,000 voters while distribution of New Iork's 45 electors arerages out to approximately 161,000 voters pex elector. ${ }^{30}$ seldon has questioned whether or not an Mlaskan is worth eight timos as much as a Now Yorker. James and Virginia Bisenatein, in a pemphlet produed for the Center for Information on America, also expressed coneern over this "inequality". Comparing the stater of Herade and Now York in the 1960 election, they found that How York had nearly 70 times an many votes cast as did Nerada but only 15 times as many electoval rotes. 31 These statistics, they say, 111ustrate one reason why the analler atates have generally opposed direct election proposals in the past. Direct election rould give every vote, ragardless of where it was cast, equal woight. This argument has been oapecially prominent ever since the supreme Court banded down the Baker V. Carx (one man, one vote) decision in March, 1962.32

Many supporters of direct election, in both large and 
small states, would like to end the system of referring an election to the House of Representatives when no candidate receives the 270 electoral vote majority. They point out that the political make-up of the House might make it unable to give a majority to one candidate. Russell Baker of the Nev Iork Times has fantagized this situation in Oux Next President, publiahed in early 1968.33 the book describes the violenee, chacs, disunity, and anarehy which might result should the country be without aresident on inaugural day and the Viee-President took command:

Bren if the Louse were unable to leot a President. under the existung arsten (stace the Sente chooses the Viee-president) it is pesaible that the tre highest officlals of the country alght be of alffering political parties. Thi could be disastous in a nation accustomed to close relationahip between its two top executires. It could be even more disastrou if the president died and the Vice-President changed policios at a time when political continuity res of oritieal coneern. The arorican Bar Association hes pointed out that lection of aresident and Vice-President from differing political parties is not an unreasonable concern, partieularly if the political makeup of the two houses of congress is different. slection of a President and Vice-President in Congress might involve political deals and pressures that would place the elected in a position of indebtedness to those who roted for them. 34 
Concern over power advantages of the states also eppere when fitousing a Howe election sine voting would be conaucted by statos, oweh atate having ano vote regardless of axze ox population.

The posalbility of unpledged alectors is another concern of those who favor direot eleotlon. At the present tim only nine state: have atetute apecifienily requiring - lectors to rote for the cundidetes nomineted by the netional party. 35 oregon is one of those stutea, but its law specifles no peand thould an eleotor voto for other than his party's oholes. 36 Although only elght of 14,018 - leotor: between 1820 and 1960 are Hleged to have roted contrary to the intentions of their upportera, 37 exities of the present aymeter any they have no falth that the trend will continue. They al to the 1960 Hepublican olector from OkI ahowa who roted for senatoz ayd for President and Sonator Goldwater for Vleo-fresldent beouse he rulntsinod the Oklahoma tetute corering loctors was unconsti tutionm. 38 Additional coneern was arouled when the aloctor, Henry D. Irwin, tentifled latar before sonate subcomaitteo houring of a "eosiftion movemont" he plakned botween the November 8 general loction and the Deember 19 weoling of -lactors. The purpose of the coalition was "to induee aufficlent depublican oleotors to joln with unpledged and Dewocratic alectora. * $.4 \mathrm{to}$ oloct a prosident other than Kennedy or Nixon." 39 In both his 1965 and 1966 state of 
the Union messages, president Lyndon B. Johnson urged the Congress to pass a constitutional amendment requiring all lectors to rote for candidates receiving the greatest number of rotes, but thus far no action has been taken. 40 Crities of the present system also foar aceidents and frauds which they belleve would be much less likely under direct election. The American Bar Association, for instance, cautions against traud ". . ance slight change in the popular rote may determine the whole vote."41 another source explains, "elose states may be won or lost by such extraneous eircumstances as rainy days or blizards." 42

Finally, adrocates of direct election beliere the systen would relieve the major parties of having to make excenaire concessions to minority groups. In 1950, Senator Henry Cabot Lodge acknowledged that the present system not only permite but actually invites the domination of presidential campign: by mall, organizod, woll-diaciplined pressure groups. 43 por example, the Liberal Party of New Iork, with a slate of elector oandidates identical to the Demoerats, determined the oute one of the 1960 election in thet state oven though the party's power was concentrated only in a fow diatrieta in New York e1ty. 44

\section{Argumente Against Direet Popular Vote}

A chief argument againat the various direct election proposals is that the aystem would permit the growth of minor partios which would likely have a divisive effect on 
national politica, Although proponents of direct election point out that the two party system has been preserved in the direct election of Senators, members of the House of Representatives, and tate governors, opponents argue that this is no assurance that the system would not break down with direct election of the President. In Electing the President, Daniel M. Ogden and Arthur L. Peterson suggest that because the two major parties are of nearly equal strength in the "pirotal" states, "direat election. . would wipe them out as decisive fectors in the election." 45 Those who argue in this rein are apparentiy convinced that third party porer ia always necessarily bad and perhaps disregard the positive offeots varlous third parties have had in our hiotory.

Cloaly related to the abore argument is the idea that direet election of the Fresident atght impair the "unifying" function of the two major parties. 46

It can be argued that the ossential feature of our party aystem is that each major party recognizes and protect the logitimate interests of all abstantial oconomio, metional, religious, ractel and othox exoups in the ration/tig 7 The unifying tunction might be limpaired by reducing the prossure upen the major partios to heed the intereste of minority, factional, or sectional groups. 47

Somo who argue egainst direct eloction say it would also deprive small and sparsely populated states of the slight advantage they onjoy through diatribution of electoral votes according to the size of the congressional 
delegation. This opinion was roiced by Richard $C$. Wel ty in the Midwegt quarterly. 48

Because of the vastness of the country and the economie importance of sparsely settled states Cospecially in agricul tural matters 7 it would be unfeir of tetes large in area but mall in population to adopt the direct rote.

Stephen Groubard writes in Gemmonweal: 49

In time abolition of the electeral college would bo a blow to the moderetion whieh mukes any candidate realise thet Jew York stoto is a collectivity of werker: and farmers, ofty drollers and town poople, Hegroos and Jows, and maxy tho fall into none of these catngerles. * .evoliling the more grand 10 se Imeges invonted by advortioers and public optaion pollin.

Graubard toars a drect popular alection would be nothing better than a "elreus dreseed up and parading as a roferendum. 150

Yal. Law Professor Alexander M. Blekel has been a major eritic of direct popular election, partieularly the reform proposed by s.J. Res. 2 in the 90 th Congress, Bickel belieres that before the 1963 reapportionment the - loctoral college did give a heary voto to cities and minority groups but that this was justified because Congress and the state legislatures were just the opposite. "Rather than being giren a diaproportionate share of power, the big cities were merely being rewarded a due share of countervailing power." 51 quoting James M. Burns, Bickel polnts out that each of our major parties is really two parties: "a Congressional party, moderate to conservative in orientation, and a Presidential party, which is pretty 
much urban liberal."52 A proposal such as that of the American Bar Association, says Bickel, would change this situation-removing the President's incentive to be a counterweight for Congress and, while a national leader, a particular spokesman for urban and minority groups. The result, he says, would be "complex and essentially undemeeratic. $n^{53}$

The Bar association proposal . . wildiy overeatimates the Immediate impact of the reapportionmont decigions and the durability of that impact. . The court hes norex insisted on mathemetical equality of the districts; and it hes nover suegasted that districting itsele is unlewful. Mor has it teckled the prectiee of Gerrymandering, which is quit to expable of achioring all that the most sophisticated system of malapportionnent could produes. . . Meither the court nor the Bar Ansoelation has yet propoed abolition of the Senate. . . the ultimate in malepportlonment. 54

Direct election rould almost ineritably bring pressure for notional laws governing quelifleationg for roting and would therefore cause great resentment among the tates and undoubtedly raise a loud cry of "states' righte". In the worda of Holty, federal control over such atters would be "counter to the theory and practice of Aneriean governinent since the Articles of Confederation." 55 Similarly, he fools that direct alection of the President could result in enlarged regulatory authority over political parties. Ho expressed shock and concern orer Senator Smith's statement before Congress in early 1961 that the "fostering of netional uniform laws on elections 
is an objective to be sought rather than opposed." 56

Clarence Davis, a member of the American Bar Association but a dissenter from its electoral proposals, says direct election "obviously results in the reating of power to the metropolitan areas and destroy the identity of the states." 57 Veshingtor Post writer Morlo J. Pusey, who oupports the Bar Ansocietion proposal, recognizes that a "aymbol of federallsm" would be lost but believes that this

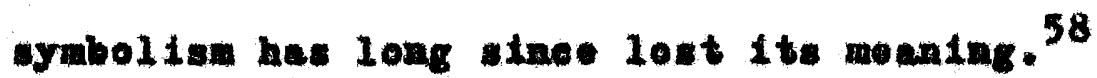

The Prosident is not aoutral ligure omerging from inagimary colloetivisation of atate interests but the vibrent champion of the popular majority. That would bo lont. . Is only a shad ow from the past. 59

Daris' cxiticise does not soem to take into socount the fact that state identity is depondent upon many larger factors then election of the Prosident-geographical, economic, social, and thnic facters, to eito fow.

Opponents of direct election maintain that the risks inherent in the present systen have been exaggerated and point out that only twies in the history of this country, and nevor in this oentury, has it been noeessary to refer an -lection to the House of Representatives because no candidate receired a majority of the lectoral votes. The New Bepublic roleed this sentimont in its March, 1968, issue when it labeled arguments in support of 8.5 . Hes, 2 as "a parade of all sorts of horrible things that can supposedy happen in a Presidential election. . most of which are ex- 
tremely unlikely and wouldn't be all that horrible if they did. "60 The magazine urged adoption of an amendment introduced by Representative Jonathan B. Binghan of Nev York (H.J. Res. 2086) "which will do a nice job without stirxing the controvergy."61 Although Bingham says he dislikes the present system, he suggested that for the time being it be kept except for one minor changes provision for a run-off between the two leading andidates if neither obtains a majort ty. 62 Bingham's reasoning was two-fold. First, he had grave, but correct, doubta that any major electoral proposal would be passed by Congress before the 1968 November general eleotion. Secondly, he reared that third party candidate George Vallace would recelve onough votes to keep oither the Demoeratie or Eepubliean candidate from winning an - leotoral majority. Walor separate logislation, Binghan sought to move the general aleotion date lato Octobor, shortening proaidentiel eampalgas end loaving time for possible rua-ofes.63

Another argument ageinet direct lection is that it would tond to Increase campalgn expenditures, which are already enormous. Henken tates, whe major parties could not undertake much more campaigning than they do now without the costs beconing prohibitire." ${ }^{64}$ It is argued that because highly populated states and large cities would continue to be good sourees for rotes, parties might be tempted to linit campaigning to those areas only, and principal 
candidates might have difficulty reaching all parts of the country. While television has practically elininated this last diffioulty, the high costs of advertising have reintrodueed the problem in a different form.

To the statement that the present systen exaggerates eloetion reaula, Attorney rienken argues that this is not alvay bod, that appearane of ctrongth nay be a "useful, perhap evon neseamary," prestige and moral force in leadlag the country, partioulerly during difficult transition paxiods aceompunging changes of adminiatration. 65

Opponente of alreet olestion Indieate that it is the most drastle renedy for the shorteoming of the present aystom. Bickel eaution agalast those who seck "purity of ideology in pelities at the cost of workebility." 66 Unirersity of Californte Profensors Molwon V. Polaby and Aaron B. Wildarsicy remind those who polat out something wrong in a eyatem permitting arosident to be leoted by less than a wajority that they should not forget "the extent to which our Constitution is in fact deaigned to thwart majority rule."67 "Ve want majority rule," they may, "but we also vant all sectors of the population to hare oqual roice in government." 68 Their interpretetion of the intentions of the "Founding Fathers" at the Constitutional Convention of 1787 apparently disagrees with the conelusions reported in Chapter II of this paper. So does that of Velty who castigater those who sec no need today for protection fron the 
"radical messes". Welty asks those who cite direct election of Senators to support direct election of the President to remember that there are one hundred Senators but only one Prosident; the risk may be greater, be says.69 wile relty acknowledges that direct election would be the most simple method and the easiest understood by the voters, he questions whether or not the country is too large and diversified for a uniform electoral aystom. He further questions a failure to recognize regionalian and sectionalism which do oxist and foresees a posible lection conoentrating power in one or two sections of the country, most likely the Northeast and Recifle Coast areas. ${ }^{70}$ The logle of his argument is difficult to follow. In light of his latter arguments, it is hard to undexstund how he car still adroeate olection of one exesutive for the entire nation. Furthermore, it should be noted that five of the tea most populous atates (IIIInois, Ohio, Texas, Mlehigan, and Floride) are in neithor the Northeat or Pacific coast aroas. 71

Grabard oppeses alreet election for yet another reason-that of breaking tradition. Ho has stated that the results of direct popular lection might be more hazardous than fallure of the present aystem and quotes the former British Conservative Prine Minister, Lord Salisbury, who asserted, "When it is not nocessary to change, it is necessary not to change."72 Graubard and other opponents of direct lection relate experiences in France and Italy to 
show how electoral reform inight come to be "manipulated" with various parties conpeting for the system under which they could most likely win. ${ }^{73}$ As Charles A. O'Neil observed nearly a century ago, "Many good measures fail to pass, and of ten bad measures succeed, on account of the near approach of a presidential election." 74 "Changing the fundamental law of the land," he advised, "and thereby shifting political power, is a most delicate ect.... "75

Lastly, and perhaps most realistically, opponents of direct election point out that it is doubtrul any such amendment could be approved by the necessary two-thirds of both housen of Congress and ratified by three-quarters of the states. At least four sujor barriers vould stand in the way: (1) some tates would be unvilling to lose or risk losing control over roting (2) the amall and sparsely populated states would oppose relinquiding what they consider an adrantege in the presont aystem; (3) Likewise, large states would be unwiling to aurrender what they consider present pover; (4) pelitieal parties would fear, and therefore oppose, a ohange in pelitical power. It la interesting to noto that no mojor political party seems ever to have supported a proposal for direct election. 76

\section{Clarence Davi has recorded:}

- Whon the report [Amorican Bar Association] was received in Washington, it was greeted mor. or less with siniles becaune the proposal has never been ablo to mustex nearly enough votes in the Senate to pess the proposed anendment.77 
However, a more recent notation by Senator Birch Bayh, Chairman of the Senate Judiciary Subcommittee on Constitutional Amendments, indicates otherwise.

It appears that the proposal that has the greatest chance of receiving affirmative action in the Senate is the proposal recomending a drect national -lection. Although in the past this propesal has lineked suppert, it is now ovident that a substantial amount of Congreasional and private support is present.78

The 1967 head of the Amorican Bar Association, Orison s. Marden, agrees with Bayh and of tos reeont favorable response erom beth Coagress and the press. He believes that the lact that the Amorican Bax Association's Commisaion on Electoral Reform was oble to reach a coneeneus is strong -vidence of changing attitudes. 79

In addition to the smorican Bar Ansociation and the Americen small businoss Association, already mentioned, other large organizations whieh hare boen active in promoting direct eloction include the Hational Grange, the Chamber of Commeree of the United States, the National Association for the Adranoement of Colored People, and the United Auto Vorkers. All of theso offered testimonies before the Senate Judlelary Subcomittee on Constitutional Amendments during the 90 th Congress.

\section{THE AUTOMAXIC SISTEM}

(Proposals to Abolish the oftico of Eloctor)

President Johnson's electoral college recomendations 
to Congress in 1965 and 1966 could probably best be orbodled in the first of three indtrect lection proposal to be considered next. It i the co-celled automatic system which would anend the constitution to retaln the electoral co11ege but abolish the offle of elector. Under this ayston, the ondidste vianing the highest number of popular rotes in atate rould autoanteally be croditad with all of the eleetexal roter in that tate. Dietribution of retes would be on the cene busis as the present ayster and a majorty, or 270 votes, would be neceneary for elaction.

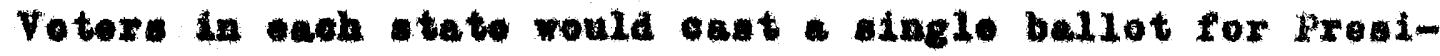
dont and Vies-proident.

Beoause it would larolre the leset mount of change of any of the majer proposels, this method is womatimes called the "minimel preposel". It rould provide for a Congrassonal election if no cendidete reoelved a majority. such an leotion, deolaed in jelnt meting the Houme and senete, would be an inprovement orer the present system whereby the Henes ohooses tho President and the Senete the V1ce-Procident and whioh involves the risk of olecting a President and Vie-president from different political parties.

Variations of this proposel have had a long history. James Madion recognised the difficulties in the present bystom as early as 1823.

The present rule of yoting for preaidont by the house of lepresentatives is so great a departure from the repubilean principle of nuwerieal 
equality, and even from the Federal rule, which qualifies the numerical by a state equality, and is so pregnant also, with a mischievous tendency in practice, that an amendment to the constitution on this point is justly called for by all its considerate and best friends.80

Three zears later, in 1826, a proposal to abolish the office of elector was introduced into Congress by Representative Charles E. Haynes of Georgis. 81

Presidont Andrew Jackson, who feared the power of electors and the probability of Louse election, spoke of the need for congress to consider sueh an amendment in his first mossage to Congreas in 1828: "There is anger of The people's] wishos being irustrated; ome [olectorg] may be unfaitheul, all axe 1iable to exr." 82

In 1878 apenial House comittee proposed to dispense with eleetore and allow the citlgen: to rete directly, although states rould posesss presidential votes equal to the number of former eleetors and these would be multiplied by the eendidates' pepular rotes. The results would then be aivided by the entire populax rote. 83 The proposal was confusing and could not arouse enough laterest to get to the floor of the Hoye for discussion. 84

Wh1. the autematic preposal rould oliminate the huan factor-whe independent olector-many eritics of the present systom would not be expected to vote for it sinco it preaerves the unit rote and would tond to "freene" this principle into the constitution, changing it from a matter of custom to a constitutional mandato. 85 As Welty points 
out, critics of the present aystem are less worried about the possible lrresponsibility of electors than the present nethod used for counting electoral rotes. 86

Because a proposed amendment of this type would require the least amount of change in the present gystem, it perhaps has a better chance of pessing than other more drastic proposals. Its opponents, howerer, otate thet it would only tend to gless orex the problem. While the "man in the streeth might feel mere oomertable knowing the office of el ector had been eliminated, the now aystem could offer ne other renarkable changes from the present syaten. It could atill peralt eleetlon of a Proident who received less roted than an opponents it could continue to disfranchise milliens of minerity roters it could perhaps magnify the poselbility of eraud or ceeldent in elections. As Dr. Paul J. Plecard, goremment profeavor at Florida State Univeraity, told a Senate subcomitteo in 1961, "An amendment should not restriet itself to remedying merely potential evile."87

Proposal of the automatic type rere introduced repeatedy in the 80th through 88 th Congresse by Estes Kefauver of Tennessee, more recently in the 90 th Congress by Wyoming's Senator Gale H. MeGee (S.J. Res. 20) and by sereral mombers in the House. None of the proposals has been able to energe from the House or Senate Judiciary subcomittees. Interest in electoral reform in the past 
two years has seemed to move away from this type of amendment toward the direct popular rote or one of the two indirect proposals which will be diseussed noxt.

\section{THE DISTRICT METHOD}

Most district mothod amendments would rotain the electoral college but would liminate the present procedure of giving a state' entire electoral rote to one candidate. Blectors, equivalent to the number of representatives in the House, would be chosen by state voters. Two electors-atlarge, corresponding to a tate's two senators, would also be lected. An effort would be mad to oordinate electoral districts with congressional distriots. Gach candidate for -lector rould be required to declare the persons for whom he would rote, and the decleration vould be binding, eliminating the denger of the independent aleetor. Tallies of rotes within each stete and the Distriet of Columbia would be sent to the President of the senete, and the candidate receiving the highest number of total votes would bo elocted, providing he recelfod ajority. In the absense of a majority, wost diatriet plans recommend that the election go to the senate and House, meeting fointly, and that the Presidont be chosen from the top three candidates.

The district method is not a new auggestion. When state logislatures began in the late 1700's and early 1800's to provide for popular chotec of presidential electors, it 
was normal for electors to bo chosen in districts similar to congressional districts. Jamos Madison has been quoted as saying that the district system was the one "mostly, if not exclusively" in view when the constitution was adopted. 88 As noted carliex, howeror, the distriet method was abandoned when partics waw that they could win more votes for their eandidates by choosing olectors on general, stato-wide tickets.

Pour times between 1813 and 1824 amendments containing raxletios of the district aysten were pessed by the Senate. In 1820 the Nouse alse roted in farer of aistrict plan, but the $92-54$ rete foll short of the required two-thirds majority. 89 Opponont of the plan at that time saw it as unsettling one of the compromises of the constitution the Foderal principle. Mary propoeals unlug the district method 1so appeered during the winter of 1823-24 but were indefinitely pertponed in comittees. Bepecially rocal on the matter was Semator thomes Eart Benton, who raged a 24 year eifort to hare a distriet mothod anondment approved. It has been stated that his opeeches on the aubject were "characterized by deep historical researoh and broad national ism." 90 19 noted earl1er, Prosident Androw Jeckson, who feared - lectora and a House election, is sald to have at one time declared himself in favor of the Benton plan. 91 In 1823 , Benton wrote: "gvery reasen which induced the Constitutional Convention to institute lectors has failed. They are no 
longer of any use and may be dangerous to the liberties of the people." 92 And in 1824 he said:

- . the general ticket system, now existing in ten states, was the offspring of polley and not of any disposition to give fair play to the will of the people. It was adopted by the leading mon of those tates. . . to give power and consequence to the leaders whe manege the electors, but it is a departure erom the intentions of the Constitution. . to give to ach mass of persona, ontitled to one elector, the power of giving that electoral vote to any cendideto thoy preferred.93

Author Charlos A. O'Holl suggests that a district -lection amendment might have pessed in the 19th Congress (1827-28) had that body not been marked by atrong personal and sectional foeling. 94 Mon who supported John guiney Adams in the 1824 presidential eleetion (decided in the House of Bepresentatives) were apparently on the defensive and folt compelled to defend the syston by which adams had obtained office. It is interesting to note that some years later, In 1842, Adans servod as chalrman of select

Comitteo in the House of Representatives, during which time be steted that the representation of the people by single districts "is undoubtedly the only mode by which the prineipl. of representation in proportion to numbers can be carried into execution. . . 195

The election of 1876 , in which Mutherford $\mathrm{B}$. Hayes scored a one lectoral rote vie tory over samuel J. Tilden, led to a "plethora of proposals" 96 but because Congress was divided on the weana to achieve the ond, none could gain momentum. In fact, no floor rote on a district plan has 
been held in the House of Representatives since 1826.97 In the late 1940's, President Harry s. Truman submitted a statement proposing a district system utilizing congressional districts, but it receired little attention.

In recent years the main spokesman for the district method has boon Sonator Karl Mundt of South Dakota. In overy Congress oince and Including the 83rd (1953-54), Senator Mund has introdued an amendment on olectoral reform. His resolution in the 89 th Congress recelved only tho minimal consideration In subcommittee, but he and eleven other senators introduced \$.J. Res. 12 when the 90 th Congress conrened. This bill was stil in subeomittee, with sereral other indlar proposals, whon the House and Senete adjourned In Detober, 1968 .

\section{Arquente in Rerer of the Dietsiet plan}

One of the exguments offered by senator hund and othere who ferer the distriet plan is that it would noro aceurately reflect the popular election realts than does the present "winner-take-all" arstem. The following descriptive pasage by sanator Mund illuatrates the disdain of many toward the present ayater:

- - one sodden drunk on fall off a park bench in Battery Park of Now York City and hitting the ground wake up and steger and stumble into a voting booth on lection day, not knowing where he Is, and, in the heat of the olection booth. to keep from falling on his tace in his drunken stupor, reach for an election lever as a support and accidentally pull the election lever down, thereby determining the entire outcome of a 
national Presidential election. . That one rote cast by Mr. Stumble Bur . . can put in action 45 electoral votes which mean more than all of the votes cast by intelligent people voting unanimousy in 12 or $9{ }^{13}$ separate states of the United States. . .98

Hudt and other adrocates of distriet election assert that it would prevent the olection of "minority" Presidents. To the extent that popular strength was reflected In alectoral roten, the posalbility of a wide disparity between popular and aloctoral rotes would be reduced. A popular mority in atato would not bo rasted. Eridence to be presented in Chaptor $\gamma$ of this peper shows, horover, that a Prealdent with fower pogular retes than a rival could hare been lected in the clese presidential contest of 1960 had alstriet plan been in efrect.

Onder the distelet arsten, ench vater would vote for only three lectera rether than for all the electors in his atato as under the present syatemi mis would reduce the difference in the value of each roter's vote among states. It is felt that a distriet rote rould also limit the possiblo effects of local fraud, bad weather, intenso local issues, and aceldental cireumstances. As for fraud and Intense loeal issues, however, it seems probable that a district lection would intensify, rother than limit, these.

The distriet plan would preserve the present provision for relating lectoral rotes to population; the total electoral treasth of stato would not vary with 
the relative size of the popular rote. Blimination of the present unit rule would save large blocs of voters in a state from being disfranchised for having amassed a total state-wide rote for a candidate less than that of the winner. 99

Supporters of the distriet plan generally seem to bo concerned that the present two party system in this country be maintained.

In any areas of so-ealled 'one party' stato which are now sometines represented in Congress by nombers of another party, the other party would be encouraged by the district amendment to soek al ectoral votes for its Presidential candidate.100

Slnee the distriet plan would not give electoral votes to minerity groups thinly seattored threughout a state, it 1. argued that the alstriot plan would tend to discourage the growth of third parties or eplinter parties. Few minorities, howerer, are thinly seattered throughout a state; they are mere 1ikely to be highly coneentrated in amall rural or uxban areas.

Adrocates of the distriet plan are among those who would like to reduce the power of large elties and doubteul states which they boliere exert excessive political influence. Likewise, the alstrict plen would make it less impertant that presidential oandidates be chosen from the "pirotal" states. Small or sparsely populated states would not be deprived of the adrantage they believe they now possess, and each state would continue to receive three 
electoral votes regardless of population.

J. Harvio Willians of the Americen Good Government Society feels that the district systom would foster needed harmony between the President and Congress inasmuch as rotes would be cast for President and Vice-President and for mombers of Congress by the same roters in the same district at the ame time. Williams pointi out that this would end the "ideologieal confile t" between the White House and Congress within party and that the executive branch would rightly be subjected to the same political pressures that are brought to baur on Congroms. 101

In an attompt to placate ateten" righters, proponents of the distriet plan illustrate that by proserving electors the district aystem would not involve any threat to the role of the states or to tate control orer voting. The amendment would, howorer, eliminate state control over the method of choosing electors. In the 90th Congress, states' rights champlons admitted that this would be wise in order to prerent possible mantpulation from one election to another. 102 Also, the systen would bind presidential electors, eliminating the sometimes foared independent elector and guaranteeing an expression of the popular will. In the Mundt proposals, only if a candidate died before the electors met would an -lector be eree to rote for someone else. Axqumente Against Distriot Rleotion

Because the relationship between popular votes and 
electoral rotes would depend partly on the geographic distribution of party strength, opponents of district election feel it would not invariably reflect popular vote results any nore aceurately than the present system. (See rable IV) Moreover, as long as the electoral college system remains and each state has at least three electoral votes regardless of population, distortion would be built into the system. Al though each voter would vote for only three electors, population disparities among states would reduce the value of a rote for stetewide electors in large statos as compared to small ones. Also, district plan might continue to permit election of a President with less votes than his opponent if the vinning oandidete won most of his electoral votes by bare majorities or pluralities while his opponent received large numbers of h1s rotes by hage margins. 103 It seems elear that serexal factor: other than the present unit rulo could contribute to the election of "minority" President. A writeh in the electorel rotes of one of the smallest states from the ronnedy to Mixon column in the 1960 - loetion could have resulted in Konnedy's receiving less popular votes than Mixon. Only .18 of ono per cent separated Konnedy's and Hixon's populax rote totels in that election. 104 Argunents challenge the fact that the district system would dininiah present inequalities in state laws. It could continue to permit states to restriet their suffrage without loss of electoral power, and the states would cast 
the same number of electoral votes regardless of the size of the popular rote.

Although some opponents of the distriet method concede that it might give minorities a better chance to be heard, the plan would in general reduce the influence of the big city rote with the possibility that the system could permit a candidate to win an election without the support of major motropolitan areas. Meal Peirce has writton:

Aa for the elaim that the distriet mothod would not diafrunehise voters es does the present system, districts would use the unit rule as the atates nor do; thorefore it seous only to be a question of of what level the disf ranebiaing occurs. 105

As Thoma: Jefferson said in 1800 (basing his comments on the then-oxisting alue of the nation and the number of distriets), "It is merely a queation of whether we will diride the United states inte 16 or 137 districts." 106

Rather than strengthon the two parties, the diatrict oystem might impair then. The Bisenstoins, for exanple, believe that the distriet ayston would be unlikely to invigorate soeond parties in one-party states, but if it did, it might inerease the likel thood of no owdidate rocoiving a majority. 107 "In all probebility," oay the Eisensteins, "the distriet syston would concentrate presidential campaigning to maxginal aistricts. "108

Eren though senator Mund and other supporters of district election have attempted to assure that electoral 
districts and present congressional districts rould be coordinated, opponents are not satisfied that this could be easily achiered. It rould not be a simple task deciding where district lines should be drawn. The prospect of gerrymandering would also have to be considered, even though Senator Mund insiats that him proposal, in inserting a heary rural blas, provides a "counter-gerrymander" provision. 109 Perhaps Senator Mund has forgotten that this nation is no longer a rural one and that metropolitan areas are exerting more and more Influence in presidential elections.

Wol ty has opposed distriet election of the Prosident because, like the present system, it is confusing--a factor which he deens neither necessary nor desirable in twentieth century Amorica. 110 He aserts that a presidential election In diatriets corresponding to house of Representatives distriets would "probably and unfortunately" rosult in -lection of a President and nombers of the House of the vame politioal party. ${ }^{21}$ ve is one who believes that the interests of the country are best served when the power of political parties in Congress is more equally belanced than at the present time and whon a President may be elected frow of ther party. This is lmpossible, he believes, undex the district gystem.

The most vigorous attaek upon a district eloction proposal ocourred in 1956 when 52 Senators were criticized 
by the then Jurior Senator from Massachusetts, John F. Kennedy, for supporting the Mund-Daniel "package deal."112 Kennedy called the bill a "hybrid monstrosity" and was convinced that liberals in both parties should fight $1 .{ }^{113}$ His reaction was fortified by a letter from Ar thur Holcombe, one of his gevernment professors tharvard, who called for "Madi eonian balanee". 114

Under the present conditions, the proponderant influenee of the big clese tates on the execum tive branch of the government oheoks the dispropertionute influence of the amall and of ton ono-idediy partisan tato in the senate, 115

Senator Paul Douglas of Illinoi joinod Konnedy in opposing 8.J. Res. 31, dragging onto the seasto Rloor "the skeletons that mont of the senators were hiding behind in their torrents of oratory."116 the amendment, said Konnedy and Dougles, was really direeted against Negroes, Jews, labor unions, and Catholies. Kennedy argued that a district plan would not help the Republiean minority in the South because the reason for Bepublican veakneas there was not the "winner-take-all" aysten but the soelal, econamic, and political strueture which hold down the voto and kept Negroes from roting. 117 connedy oationed that the proposed distriet syoten could change the whole political habits of the country "with reaults which are hard to predict now." 118 He added, "One should not take down a pence until he knows why th way put up."119

In his Ameriean Heritage article, Seldon points out 
that the proposed district amendment in 1956 probably looked dangerous to the Kennedy canp and other Democrats in what they knew was predicted as a close election, that they undoubtedly felt safer following tradition and hoping that electors followed their general tradition of not ignoring the popular cholee of their states. 120 Seldon's analysis makes Konnedy appear as an opportunist concerned only with the results of partieular election yeax. In view of the extensive arguments in the 1956 Congressional Record, this cannot be considered an honest appraisal. Both Kennedy and Douglas were deeply concerned with the future effects of the amendment they opposed; they repeatedly askod their colleagues in the Senete to view the electoral college in the whole perspective of the political system, as one would view alanet in the wolar syatem. 121

Within Lew day of the Konnedy-Douglas attack, ten of the original sponsors deserted the bill, and it failed to muster the necessary two-thirds vote. 122

In the past decede support for district election amendments outaide of Congress has otemed mainly from the American Good Government soelety under the directorship of J. Harvie Williams. The Chamber of Commerce of the United states has declared itsole in favor of oither a district plan or direct election. It should be noted, however, that both Senator Bayh and Mr. Wilmerding, former enthusiastic defenders of district method amendments, have in the past 
two years swung their support to direct election amendments.

\section{THE PROPORTIONAL PLAN}

Since 1947 various proportional plans have dominated olectoral roform proposals, over 70 having been introduced into the House and Senate in twenty year span. 123

Like the distriet plan, the proportional plan would ubolish the electoral college but retain electoral votes. However, the electoral rotes in each sta would be apportioned ameng the candidates in accordance with the nurber of popular votes they received, thereby abolishing the current "winner-take-all" practice. For example, a candidate who received 60 per cent of the popular vote in the state of Oregon would reedive 3.6 of oregon's six electoral rotes. The candidate with the most olectoral votes throughout the nation vould be elected Prosident if he received a cortain percentege of the total rete. Most amondments, such as S.J. Res. 3, 7, and 84 intmodued into the 90 th Congreas by Senatera Smathers, Holland, Sparkman, Ervin, and Dodd, would require a 40 per ent plurellty. In case no person recelved the required vote, the Senate and House would jointly choose the President from the persons having the two highest numbers of electoral rotes.

The flret proportional type anendment was proposed in 1877 by Representative Levi Maish of Pennsylvania. 124 
Several times in the nation's history a proportional type amondment has nearly passed. Vigorous debato in the subcomitte aparked a 1930-32 effort by Reprosentative Clarence $F$. Lea of California, but Iike countless other amendments on electoral reform could not be brought to the floor of Congress for rote. Perhaps the best known single amendment wa S.J, Hes, 2 and H.J. Hes. 2 in 1950, the Lodge-Gossett plan, which passed by a-thirds rote of the Senete in Pobruary of that yoar but was blocked in the House Bules Committoo. 125 Reaction to the LodgeGossett amondment wes a revereal of traditional attitudes. Conservatives of both partios supperted the amondment whlle liborals of both parties opposed it. 126 The anendment had boen introduced amul taneously in the senate and House by Meseachunotta Republiean Senetor Henry Cabot Lodge and Toxus Denoeratie Repreneatetive Gd Gossett. Gossett reintreduced the bill in the sand Congrese 127 (1951-52, H.J. Row. 19) and a smilax bil1 (s.J. Res, 52) was introduced into the Senate. Both were reported fevorably in theix renpeotive bodles but recelved no further tion. 188

In 2956, Sonatox Priloe Danlel eombined proportional emendmont with a detriot loction plen initiated by senator kundt. S.J. Hes. 31 of that yoar became known as the "Daniel substitute" or Mnd-Daniel plen. 129 over 50 Senators co-aponsored the amondmont which would have 
permitted oach state to adopt ofther alstrict or a proportional plan. A state could then have distributed its electoral rotes among the top three oandidates aceording to the statewide popular rote, or, if the atate legislature preferred, the electors could be chomen as Senators and Representutives are now ohosen-two by statewide rote and the rest by congrenatonal dietriets. Sonator Konnedy' and senetor Douglas' rigoroun opposition to the b111 and 1ta consequent fellure has already been discussod.

In eaxly May, 1968, ault was IIIed in the U.S. District court in sun praneiseo atteoking the eloctoral colloge and eaking the court to lowu an order requiring ereh ata delogation of eleotor to oant votes in proportion to the reaulte of the populax election. The foux plaintiffa, two Demoerats and two Ropublicans, alleged that the present wothod of soleoting the President riolatos the due proseses guerantees of the constitution. They aked for formation of apeiel three-judge court and for apedy sehoduling of argumonts so that deeision could be reached before the November general eleotlon. 130 The four were apperently fearful that in 1968 Ameriea might egain eleot a Prosident with fower popular votes then his opponent. Like the Suprane Court in Deleware v. New Zork in 1966, the Distriet Court took no action on the sult. ${ }^{131}$ 
Arguments in Favox of the Proportional Plan

Those who faror amendments wich would institute proportional plan point out thet of the indirect election proposal. it would com closect to electing a president in secordance with the popular rotes, but at the same time it would preserve a bute relative lectoral strength. Lore egetn, the argument of 111 usory electoral atrongth is brought up-"H eoble basis for the oxercise of power [Whighy may loed to abues of euthority."132

As for the poesibility of electing aresident hering forer rotes then hls oppenont, Mesride otates that a proportional araton rould ond all ohenee of this "unaemocratie posaibility" 133 with a proportlonate alstributlon of alectoral rotoa, eandidate with majority of popular rotes could not lose the election bocause he won moat of tho eleotoral votos by lerce majoritios while his opponont reaelred his rotoc by bare mejorities or pluralities, Othor tatisties, howerer, do not support this argument. In a careful stato-to-s tete analysis of the 1960 election, the VIrginia Comission on Constitutional Gorerment otimated thet under a Lodge-tosett type propostlonal plan Kennedy rould have rocoived 265.623 electoral rotes and Nixon $266.075,134$ both short of the 270 electoral rotes needed for election. As far as the present unequal weighing of atates is 
concerned, backers say the proportional plan would give - qual weight to individual popular votes oast in pivotal states and in states where one party is almost certain to win by wide margin.

Proportional distribution of electorel votes would give eron a hopeless minerity. . a chance of orediting their candidate with some loctoral votes. 135

This plan would caloulate electoral rotes to the nearest one-one-thousandth, and abolition of the position of -lector would guarantee that no complication would arise from the inability of elector to ment and rote as expeeted. Furthermore, eonfusion created by long lists of - loctoral colloge andidates, still whown on some state ballote, would be eliminated.

Al though proponente of every type of emondment clalm thoirs would tond to broak up aolid or on party states, wach as in the south, proponente of proportional -lection spok loudent on this polnt. Because a llepublican rote would count oren in a atrongly Democratic state, orery effort would be made to bring an many roters to the polls an posablo. Likerieo, Domoeratio activity in parta of Now Hnglend and the Midde wost would be utimulated. It would not, howovor, "unduly oneourage oplinter parties or ald one party at the expense of others."136 the 40 per cent provision necessery for election should check any tendency towaxd the breakdown of the two perty sys- 
tom. Also, if an alection were thrown into the House, the President would be chosen from the top two candidates only.

Those who favor a proportional plan point out that it would free major parties from having to make concession: to minoritios in koy states; the minorites would be deprived of any power they may now posaess to "throw" - loctoral rotos in a pirotal state to whioherer party offers them the best terma.

MeBride believes that the proportional system would - stabliah a more equitable belance of power among states in presidential eloctions. A candidate who can carry six ox seren of the largent tates under the prosent system i. almost cortein of eloction. 137 Candidates cannot now afford to aproad thin thotr time and monoy and must concontrate on thone fow tates. MeBride belloves that two large evila reoult from this stubtion: (1) citizens in other otates are deprived of the duestional value of a compalgn, resulting in a lesened concern for national affaira; (2) domination of largo statos makes them able to diotate terwa to partios in return for state support, which is morally degreding. 138 Und or the se swe circumstances, prealdentiel candidates are pioked from the large states. Blimination of the electoral college and adoption of a proportional amendment, says MeBride, would widen the 
fleld and establish greater equality among presidential contenders. An analysis of MoBride's axgunents is not as fool-proof as he makes it sound. It would seom logical that even with proportional splitting of eleotoral votos candidates would be incilned to first seok out those large areas which posess the most votus. Fur thermore, in an age of wideapread telovimion, which reoches into 94 per cent of anoxican homes, 139 it is diftioult to necept the theory that eltisen of any tate is really deprited of a camplgn education. MoBride should look furthor to discorer the ressone for whet ho labels as a lessened coneern tor antional affairs.

Lastly, proportional adrocaten bolleve that the nothod would not likely threaton the powers of the states to regulete voting requirements. They are reallstic in acknowledging that anondment openting the door to notional control would hare diffioulty belng pansed by the neceasury two-thixds of congress and ratifled by three-fourths of the atates.

Arcumente Aqeinet the Proportlonel Lethed

One opposition to proportional plans is the belief that they would have undesireblo offect on the nation's parties. By allowing a minority group to win olectoral rotes, proportionate distribution would give minor parties more ineentive to build up etrongth than they hare under 
the present system. Requiring the winning candidate to receive at least 40 per cent of the electoral rote would provide only a partial deterrent to the rise of new political groups, and aplintering would be encouraged. Tienken has written:

Tho fuet that the two-party ysten has generaliy survired in Congrenslonal, gubornatorial, and - ther sopate and locel al eotions doos not prove that it would ondure indorinitely in national eloctions. Hew parties rould not have to win the Presideney in order to exereise political power, thoy could exert ereat influence by bolding the belance of power. 140

Several Congeasumen expressed this fear when they roted against the Ledge-Gosedt andmont in 1950, stating that 1t would oreato a multi-perty "Prankneteln".141

Opponents to proportional plans have pointed out that such a sotom might result in less wetivity by the anjor parties to unify diverse politieal groups. Since the oxisting systen gives the major parties an incentive to seek the rotes of minorities in key tates, it helps assure that interests of those group will be represented.

As long as both major partiea give recognition to the interests of minority groups, the mombers of such groups have 1ittio incentive to rally bohind extremist and form apecial interest blocs or partles, 142

A proportional wethod, by roducing the political importance of minority groups in the large doubtful tates, would make it possible for major partios to give less attention to the interests of the minority groups-- 
economic, sectional, national, religious, racial. As Tienken indicates, many opponents feel national unity would be jeopardized under the proportional system it any minority groups wero "systomatically under-represented." 143

Herbert Hechsler, Columbia University law professor, roleed the opinion that such a plan as the LodgeQosa tt proportional mendment "would work a major alteration in our Presidential politics." 144

There is no reason why actioning of olectoral votes should give new perties more appeal or more capacity for growing than the popular vote: they nov obtaln. A mere locteral chowlug can do nothing more than change the wathematies of fa11ure.145

Wechsier warned thet the anendmont might work to nolldify adherence to one party, that reducing the influence of state with lareo lectoratea accuatomed to close voting would correlatively raise the power of almgle-party statos. 146

Polsby and wlidergy argue thet proportional distribution would provide no asurane that the popular will would prevall in prosidential elections. The lectoral vote, including the two rotes for each Senator, would continue to be weighed in faror of mall states. A singlo vote in a sall btate where the number of total - lectoral votea relative to population was high would have more Influence than single vote in a large state. These authors aggest that large tates would, in effect, 
be "neutralized" by dividing the electoral vote proportionally between candidates. 147

It is elso argued that an election by both houses of Congress, if no candidate receired the specified number of rotes, would not guarantee more accurato expreasion of the peoples' wishos. Also feared are deadlooke and the possibility of a third party or faotion of a major party dietating the rosults of an election or obstrueting the decision al together. Large states would be expected to oppose oongreselonal election where, as proviously montioned, statos would vote by unitis and where Nevada's threo eleotoral rotea would carry the samo weight as Wow Iork's 43 eleotoral rotes. 148

Opposition to proportionel amendments frequently conters around cencern that statos would lose inportance. Acoording to Tloakent

Now a te to is 'earried' by one paxty or another, and state political organisation: win power and prostige on the strongth of hoving delivered' a stat to their preatdentiel condidete. It can bo argued that this holpe to malutalin desireble diepersion and deeontralizatipg of politieal power in the onitod states, $149^{\circ}$

Crities of proportional amendments have illustrated that the amondmonts would not roduce the prosent inequality of roting qualifications in atates and that "no penal ty would be attached to low roting participetion." 150 Fur thermore, with electoral votos of the tatos aivided 
percentage-wise between various candidates, competing groups in the states would probably tend to be merged into national groups. State party organizations would be unable to clain credit for any mor electoral votes than they could win by their share of the popular vote. Likewise, proportionate distribution might cause campaign. to be organized to exclusirely on ational basis, whereas the present system oncourages eampulgaing on a tate-byste to basis. It has beon auggestod that campaigne oriented around wtate: may take the lasues to the people more effectively then eapelgne difected toward the whole country. Thil ettitude sooms hard to necept, however, in a country whowe national probloms trenseend stato boundaries.

Proportional gpononts play dow the lidea that the present aysten, which in aceused of exaggerating the winnex's majority, is an "unmitigated ovil". 152

After a bitterly-fought -leetion canpaign, an appearance of nation-wide bueking . . . may holp to win genoral aceptance for a victorious andidate. Whd or proportionete distribution the winner would almost nover herf more than bere jority of electoral rotes. 153

One reason for opposing a proportionel amondment sooms to be that it might wet as an "opening wodge" por most drastic ohanges, one of which might be pressure for proportional reprosentution in Congroses 154 If proposed amendment gave eleotoral roten to small party 
which could not elect member to Congress, the small party might be encouragod to demand that tate congressional delegations be divided ecording to the number of popular votes received by rarious partiea in the state. This would Involve a shift from oingle to multiple member diwtriets and less dreet roletionahip between member and constituont.

Harry Louls Seldon has atod as aposemen for opponothe of proportionel emendments who assert that the conoticution should not be amended unlese it is certain that the general welfere w111 benefit as a rosult. seldon points out that the preapat mothod hes been reasonably saticteotory. 155 This was a tand taken by Konnedy in 1956:

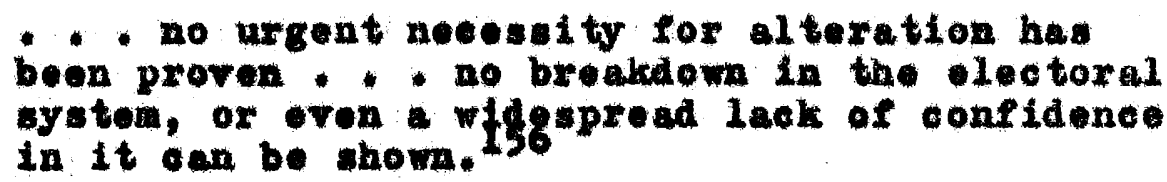

In his defonse of the status quo, Konnedy celled to attention the fact that no "minority" Prealdents have been elected in the trentioth contury. 157 the word "minority" applied to aresident is a confuaing term. Konnedy undoubtedly meant that no preaidents in this century have trailed their opponente in the number of popular votes received. Aotually, howerer, Wilson in both his torms and Truman in 1948 were "minority" Presidents in the sense that they received less than half of the 
popular vote; and ironicalily in 1960, though Kennedy won with 303 (62 per cent) eleotoral rotes, he received only 49.54 per cent of the popular vote, 158 
CHAPTaE $\mathrm{V}$

HIPOTHETICAL RESULTS OF PAST ELECTIONS

All serlous analyses of electoral college reform erentually inslude a discussion of the hypothetieal effects the rarious types of proposed amendments would have had in partioular election yoars. Such speculation is Eroquently used as "two edged oword". " Where it is show that aroposed system would not have al tered past results, it is argued that an awendment would be useless. On the othor hand, If it an bo mown that ayatom would have cauned a different reault and eleoted the "wrong man", this too is argued agalnut a proposed change. The olawile example of this, whioh appears in numerous sourees, 14 that Abrahan hineeln would probably heve not been eleoted Prealdent of the united states and would certialy have not beon remelec ted had a proportional or district plan been in effect.

Lengthy zesaneh projeets and computerized studie: of pent olvetlons have beon lneluded in the rarious publication: coneernod with the electoral college. However, vritera are in dieagreement as to the importence of tudying hypothetieal leotion resulta. To this writer, it seoms wise to follow the advice of election analysts 
and political acientist who tostified before the Senato Subcomittee on Constitutional Anendments in 1961. They cautioned that it is generally not realistio to apply a proposed change to past eloction without strong qualifieations and with the und orstanding that the statistics illuwtrate only hypothetienly the operation of a partioular plan.?

any alferent arotem would here produced moh differeat pasty platforms, eampaign strategy, and teohniques of roter appeal. Voting pettorns and partidipetion would rary: Indeed, tho nominees might not here been the save in any givon eloction If alfforent arstem had been in use. 3

At lenst wowe oredibility, howerer, must be given to hypothotical resulte, for mavy have boen caxefully rosearched and have tried to take into consideration factors which might have been at work in an election utilizing ofe of the proposed omendments, Such results are Illuatrated In Tables III, $V$, and $V$ in this chapter. The reader will note the wide direxgeney in the numbers of lectoral rote: whleh candidate: vould have $11 \mathrm{kely}$ receired under the verious proposals.

In Tuble III on page 76 , the reader w111 note that two figure: axe given for Konnedy' popular rote totals because analysts disagreed on how to calculate the due to the "dofection" of one of six unpledged Alebame electors. The Assoeiated Fress attributed to the Democratic 
candidate (Kennedy) the highest number of rotes cast for any Kennedy olector; the Congressionel guarterly took the highest rote cast for any Alebama elector and gave Kennedy $5 / 11$ of that figure. It may be argued that net ther method is setisfaetory. Counting rotes by the first mothod would lavolve counting most of the Alabama rotes twice. The second mothod beses the popular vote on the lectoral votes rather than the other way around. 4 As Folix Morey has stated, calculating the Alabama rote in 1960 was "beyond the abilities of an Binstein." 5 lom Wloker, Hew York Himes Woshing ton Bureau Chief, has commonted; "Nobody mow to thil day, or ever will, whom the Arican poople really elooted president in 1960.16

\section{TARLE III}

1960 ELECTIOA RGSUTS AND MPOTHETICAL RESULTS OP VARLOUS WEORY PROPOSALS7

(270 electoral rotes required to win)

\begin{tabular}{|c|c|c|c|c|}
\hline & $\begin{array}{l}\text { Popular } \\
\text { Yote } \\
\end{array}$ & $\begin{array}{l}\text { DListriot } \\
\text { Mundt pleal }\end{array}$ & $\begin{array}{l}\text { Eropor- } \\
\text { tionel: }\end{array}$ & $\begin{array}{l}\text { Curront } \\
\text { System }\end{array}$ \\
\hline Kennedy & $\begin{array}{l}34,050,342(A P) \\
34,221,349(C D)\end{array}$ & 245 & 265.623 & 303 \\
\hline Mixon & $34,108,546$ & 278 & $\begin{array}{l}266.075 \\
-60 \text { ssett }\end{array}$ & $\begin{array}{l}219 \\
\text { varioty) }\end{array}$ \\
\hline
\end{tabular}

Newl Polree has writtons

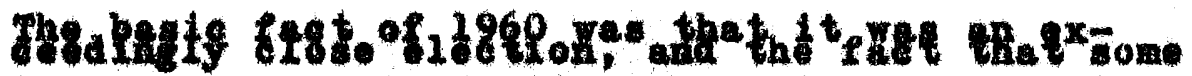
other aystems of counting the rote show silght Konnody margin and othor: olight Nixon margin is primarily an Liluatration of the lement of pure chance in any aystom undex which two candi- 
dates receive virtually the same number of votes cast out of alnost 69 million.8

Had the direct popular voto been in effect in 1960 and had the lection not been confused by the Alebama rote, Kennedy would hare received more rotea than Nixon, but neither would hare obteined a mority, The lection would have thon been referrod to Congrese where a roto by statea would probebly have elected hixon 26-23.9 Under a populax vote anondment such as $3 . J$. Res. 2 in the 90th congreas, beth mon would have qualified under the 40 per eent plurall ty stipulation, but Kennody's alight edge would hare eatapulted him to the preaideney.

Hed the distriat method of counting rotes been in effect in 1960, Mixon would have been elected by a 33 vote margin, considerably out of proportion to hls popular vote totals. It seems olear that the diatrict method of rote counting would not correspond to the popular rote totel. any moxe closely than does the current "winnor-take-all" practice. (See reble IV)

Although the proportional wethod comes closest to roploeting the popular rote totals, proportional roting in 1960 would have also resulted in the loction of Nixon al though he would have been nearly four votes short of the minimum 270 noeded to win. In a House election, however, that body would have probably sustained Nixon's victory by two votes. As Senator Paul Douglas estimated 
in his extensive 1956 study of lectoral reform measures, proportional splitting of electoral votes would frequently prevent any oandidate from recoiving the required 270 vote minimum election of the President in the House of kepresentatives would become common occurrence. 10 Table $V$ on the following page documenta that in at least alx instanses in this century, besidea the 1960 election, neither major candidate would have recelved the necessary - Lectoral voto majority.

\section{YABLE IV}

COLPARATIV ELAC TORAL VOTES CuRnar AMD PROPOSED DISTRIC SYSTEM ${ }^{11}$

Year Ropulax Aetual Electoral Probable tectoral

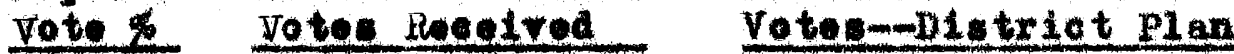

\begin{tabular}{|c|c|c|c|c|c|}
\hline 1952 & $\begin{array}{l}55.1 \\
44.4\end{array}$ & $\begin{array}{l}\text { Biceahowex } \\
\text { Storengon }\end{array}$ & $\begin{array}{r}448(83 \%) \\
89(16 \%)\end{array}$ & $\begin{array}{l}375 \\
156\end{array}$ & $\begin{array}{l}(70 \%) \\
(29.5 \%)\end{array}$ \\
\hline 1956 & $\begin{array}{l}57.4 \\
42.0\end{array}$ & $\begin{array}{l}\text { Lieenkower } \\
\text { Stevonuon }\end{array}$ & $\begin{array}{r}457(86 \%) \\
73(14 \%)\end{array}$ & $\begin{array}{l}411 \\
120\end{array}$ & $\left(\begin{array}{l}76.8 \% \\
22.4 \%)\end{array}\right.$ \\
\hline 4 & $\begin{array}{l}61.0 \\
38.5\end{array}$ & $\begin{array}{l}\text { Johnson } \\
\text { Goldwater }\end{array}$ & $\begin{array}{r}486\left(\begin{array}{l}90 \% \\
52\end{array}(10 \%)\right. \\
\text { (10\% }\end{array}$ & $\begin{array}{r}466 \\
72\end{array}$ & $(86.6 \%)$ \\
\hline
\end{tabular}


TABLE $\mathrm{V}$

COMPARATIVE ELEC TORAL VOTES

CURRENT AND PROPOSED PROPORTIONAL PLAN ${ }^{12}$

\begin{tabular}{|c|c|c|c|c|}
\hline Yoar & $\begin{array}{l}\text { Popular } \\
\text { Vote } \%\end{array}$ & $\begin{array}{l}\text { Ae tual B1 } \\
\text { Votes Reo }\end{array}$ & $\begin{array}{l}\text { loetoral } \\
\text { celved }\end{array}$ & $\begin{array}{l}\text { Probable gloctoral } \\
\text { Yotes--Proportional }\end{array}$ \\
\hline 1900 & $\begin{array}{l}51.7 \\
45.5\end{array}$ & $\begin{array}{l}\text { Mekinley } \\
\text { Bryan }\end{array}$ & $\begin{array}{l}292(65 \%) \\
135(35 \%)\end{array}$ & $\begin{array}{l}217.3(48.62 \%) \\
217.2(48.59 \%)\end{array}$ \\
\hline 1904 & $\begin{array}{l}56.4 \\
37.6\end{array}$ & $\begin{array}{l}\text { Rooserel } \\
\text { Parker }\end{array}$ & ${ }_{140}^{336}\left(\begin{array}{l}72 \% \\
29 \%\end{array}\right)$ & $\begin{array}{l}268.5 \\
179.0\end{array}\left(\begin{array}{l}55.6 \% \\
37.1 \%\end{array}\right)$ \\
\hline 1908 & $\begin{array}{l}51.6 \\
43.1\end{array}$ & $\begin{array}{l}\text { Taft } \\
\text { Bryan }\end{array}$ & $\begin{array}{l}321 \\
162\end{array}\left(\begin{array}{l}66 \%) \\
34 \%)\end{array}\right.$ & $\begin{array}{l}230.8 \\
286.9(47.8 \%)\end{array}$ \\
\hline 1918 & $\begin{array}{l}41.9 \\
23.2\end{array}$ & $\begin{array}{l}\text { Wilaon } \\
\text { Taft }\end{array}$ & ${ }_{8}^{435}\left(\begin{array}{c}(89 \%) \\
1 \%\end{array}\right)$ & $\begin{array}{l}246.7 \\
113.9\end{array}\left(\begin{array}{l}46.5 \%) \\
21.5 \%\end{array}\right)$ \\
\hline 1924 & $\begin{array}{l}54.0 \\
88.8\end{array}$ & $\begin{array}{l}\text { Coolidge } \\
\text { Davis }\end{array}$ & $\begin{array}{l}382 \\
136\end{array}\left(\begin{array}{l}71 \% \\
26 \%\end{array}\right)$ & $\begin{array}{l}258.8 \\
191.4\left(\begin{array}{l}48.7 \% \\
36.0 \%\end{array}\right)\end{array}$ \\
\hline 1948 & $\begin{array}{l}49.5 \\
45.1\end{array}$ & $\begin{array}{l}\text { Truman } \\
\text { Derey }\end{array}$ & $\begin{array}{l}303(57 \%) \\
189(36 \%)\end{array}$ & $\begin{array}{l}258.0 \\
221.4(48.6 \%)\end{array}$ \\
\hline
\end{tabular}

*Lodge-Gossett type 


\section{CHaptua VI}

\section{CovClus Ion}

Af ter all of the arguments heve been heard, this writer belieres that it id impossibie to justify maintaining an electoral araton which oun thart tho desires of the atbigens. The eriticiume and posalble dengers of the present aystem are elear and are used by apporters of all propesed plane. Yet, Intrieate apeeulative rosearch Indieates that none of the ladireet proposals can offer a botter, or oren equal, guarantee of vor equality in the clection of the President, From the diatriet syatem proposed in the carly 19th entury to the proportionel ayetom edvaned most prominontly after Vorld Var II, each plan has had ite dey and has been found wanting. In the words of Tow Vicker, "Reeh aystem has oome ont of the pock 11ke ahallenging horees only to fall back in the hoves tre teh. 1

Arguments used to support each of the various alternatives to the present gyatem are etrikingly aimilar; only the intexpretations of the "facts" alfer. A roview of the arguments makes one feel that each group is merely standing at different vantage polat, sometime blinded by how alose theix positions really are. Each group hes 
Its own "pet delusions" for justifying why a particular system should be instituted, ither not willing or not able to see the roal cause behind what Senator Douglas once identified as "torrents of oratory"2-that which when tripped of all the niceties my be reduced to one cause: power. It seems that leaders of the various reform offorts have often put stato or personal interests before national interests. This is inexcusable in the election of one ohief executive for the entire nation,

Purtherwore, it cannot be atad too emphatically that the "evidence" called forth on bohalf of the rarious - lectoral reform proposals must, In the linal analysis, be viowed as what it is--highly speulative. The 1956 Senate debate on electoral reform clearly pointed up this problem. Wo atmply do not and cannot know for cextain whet the polltieal resulta of the raxious proposals might bo. Mis writer belleves, howerer, that the direot election proposal would in no toreseeable way harm the nation. In a reout series of interviews with manager: of prestdential campaigns--formex Postmastex General Lawronec OHBien, Senator Thruston B. Morton, and othersNeal polrce found that they also expected that the direct vote, unlike other proposed reform, would have little Impeot upon the existing otrategy of preaidential campaigns, lncluding the role of political parties in presi- 
dential elections. 3

On the other hand, the dangers inherent in the present systom constitute real evidence which, like a dormant voleano, could apring to life in any prosidential - lection. Most foered are the election of a Rresident who is not the pooples' favorito, a House election, and the posalbility of unpledged electors. All of these would be incongruous ith demoeratie government which purports to emphasize the value of Its individual citisons. The netion cannot afford to retain this undemocratic Inotitution. Should the present system fail to - lect the candiate with the nost popular rotes, the reperoussione both at home and abroad could be unimaginebly demaging. An Pelfee hes indicated, the problems under the preaent oystom are most intenec in a close election, "and then wo almply cannet gauge the havoc 1t Lhe present aroteg7 might cause. 4 It could reaken the athority of the Prosident or disrupt continuity in turbulent times; and in the ovent of a Houne lection, there would probably be "wheelfing and doaling" bofore the electors voted in mid-Decomber it womeone tried to force a "deal" upen one of the majox oandidates. Qren if he could not toroe bargaln, the prosideney might be cheapened by his efferts, and the only deeent solution would be for the House to select the man who received the most popular retes. If this were the case, a dixeot vote 
might just as well have been in effect. And Inasmuch as approximately one-third of our Presidents have been elected by less than a 50 per cont rote with no apparent problema, the Aweriean Bar Association's recomendation of a 40 por cent plurality soems wise.

Direct election is perfectly understood by the people and, as already Indicated, a mojortty of Americans thinks it al ready exists. It is the system wanted by them, and It has proved workable in eleeting every other offleer of the United states, ineluding gorernors of statos with million: of inhabitants. Senato Majority Leader Mike Mansfield has statod,

[Th7 rederal system is not streng thened through an antiquated deviee whleh has not worked as it was intonded to work whon it was ineluded In the constitution and which, if anything, hes become alvidive foree in the Poderal system by pitting groups of atates against group of states. An 1 see the Federal ay tom in contemporary proetloe, the Houwe of loprementatives is the key to the protection of diatrict Interesta as distriet intexesta, junt as the Senate is the key to the protoction of state interests as state interabts. Those instrumontalitios, and paxticularly the senate, are the prinoipal constitutional safoguards of the Fodoral aystem, but the Prosideney has ovolved, out of necessity, into the priaeipal polltical offloo, as courta have bocomo the prinolpal legal bulwark beyond dietrletw, beyond states, for onfoguarding the interestis of all the poople in 211 the states. And since this is the case, in my oplaion, the Prealdency should be subject to the direct and equel control of all the people.5

In the words of one of the carlilest advocates of the national plebisolte systom: 
What could make us so much one people, as to give all the poople this general equal privilege? It would produce in the national habits, manners, and love of country, more harmony than any othex political measure which could possibly be adopted, 6

Pormer lepresentative Lea once said:

I know of no legitimete reason why overy candidete chould not receire all votes eat for him. Those are just basig requirements of a just aystom of lection?

As John Banshat has recorded in the V11lanova Law

Leview:

Indeed, if the cholee were almply between the axisting unit-rote syatem and the proposed proportional or aletriet ayatems, one would ingly be declalig which croug of roter:those in the lares atates ox those in the saal1-would be giron an unfalx advantage in the election of the President. * But there is an alternative a drect vote of all the poople." " the only plen that would give

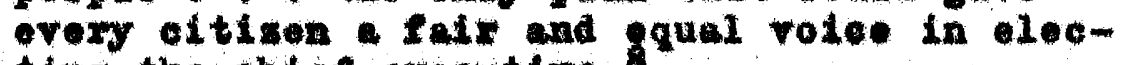
ting the ohlef exeoutive.

since the Conetitutional Convention, debates on the leotion of the Amerlean Prestaent here become bogged down in a conelderation of big tate roxac small state intercate. Danghaf maintalns, hoverer, that such arguments have been eoupletely irrelevant.

Nowe of the great battlos of anexicen political history-in Congress, or in presidential llectlon-mes boen fought on the besis of suall rersus large thtes. The erguments have had ldeologloal, coononto, and rogionel points of deperture-but never he the line of de-
mareation been besed on the lse of the states. 10

Banghaf pointa out thet only in the "aethereal realas"11 of constitutional debate have the differences between big 
and small states been rital. He accuses those who defend plans other than the direct vote of ignoring one basic factor-mo individurl citizen's interest in combining his vote with other voters who share his leelings. No matter how great his theoretical power may bo in a Preaidential election, a roter is -ffectively disfranchised 11 he happens to be in the minority in his state in his obole for prosident. Under the unit-rule system, his vote (or the lectoral vote representing him) is then aetually cast for the candidate he opposes. And this is true whether he is libersl or conservative, whit to or black, John Blreher or now, feft, or a mall-atate or largestate eltizen. 12

Untimately, of courae, this roter's preferred candidate may win the eloction, oren so, his onthusiasm must be somewhat dampered by the roalisation that his rote cast in a "losing" state played no role In that viotory. Banzhaf also lawhes out ageinst epologists of apecial big atate power in the elocteral college, saying that they have zeally beon trying to defond the ability of Ilberally-oriented minority groups--Negroes, Jews, unlon mombers, and assortad "Q thalos"-to exercise spectal woight in prosidential oloetions. 13

But in the exw of whito 'backlash' and organized groups of the militent $x$ ight, it is no longer cortain that the 'bloc' rote in the big atates-m if it orex was as malleable ou gome depictedwill be liberal in oomplexion. 14

Certainly, there should be e eirmer theoretical justification than wo preaently have for the system by which we elect a wan with the national and global powers 
of modern Prosident. In The American Prosidency, 15 historian Clinton Rositar issta ten major roles of the modern President (1) he is the chief of state, ane man distillation of the Anexiean people, (2) he is the chlef oxeoutive, the manager of the gigantie federal apparatus; (3) he is the comander-in-ohief; (4) he is the chice alplomats (5) he io the chief leglisator: (6) he is oniet of his party (7) he is the protector of our netional pease; (8) he 1a the leader of a coalltion of fre nationa; (9) he it the maneger of prosperity; and (10) he 10 the roiee of the poople. Glecteral reform must be inctituted, howerer, if the Frealdent is really to be the voleo of all 200 million Anericans In practice as well as in theory. As senete Judielary subcomitteo observed in 1964, "Wo cannot continue to and U.S. Pxosidente of the spaes age Inte offie in the oxcart furnished by the lectoral college." 16

Change 1: needed in the method of eleoting our President, but is it possiblet

In 1895, Charle A. O'Heil wote in the American Electoral Bxteten:

Reform is not possible in these quifet times. Some greet and grievoul wrong must be perpetrated before a ohunge can be offected. The people nut be legally robbed of the Preaideney. . 17

Al though few people today woula label ours "quiet times", anyone who analyzes the hundreds of electoral reform 
measures submitted over the past one hundred eighty years must be struck with the fubil1ty of any change. In 1958 Luolus W11merding echoed 0 Nell's sentiments:

- perhaps nothing 111 be done until misfortune striken-the aystem talis and a choice In the House of Reprosentetive is plainly obnoxious to a majort ty of the people.18

And Rlohard 0 . Welty has oald:

Conetitutionel changes . are often possible only atter eriels resulting from sone inadeque to proecdnee. - perhaps the Anerican poople 111 cemand ohange befor such a crisis oocurs. 19

A. provlously Indiested, direct popular vote seems to hare gained momentur within Congrese in the past two yoare, partioulerly in the senate. Soveral Congressmen have cone to realige that adoption of a distriet or proportlonel plan would nost likely tarn in somo old problems for wowe new ones. In 1a te January, 1968, the NeV Republis Indleated thet Senator Ban Arvin, who has for yeare beon ajex foree behind proportional amondments, seomed to be "aortening" toward direct populax rote. 20 If this is true, the direct rote may ladeed tand a better ohance than it has for years, for senator Irvin 1. said to have influense orex approximately 15 to 20 other senetors on conetitutional questions. 21 Senator Bayh reported that direct election had the aupport of seren of ton mowbers of the 90 th Congressional subcommitte on Constitutional Amondments. 22 Bayb foels 
that if the subcomittee gives its approval, there will be little difficulty getting an arenament to the Senato floor "where it would stand a good chanee."23 Hope of its passing the House, howerer, is thought to be much more d1m. 24

At the present time, it seems epparent the t any Impetus toward eloctoral reforw will have to come from within Congress. Despite the high percentege of Anericans aela by public optaion polls to faror electoral college reform, and desplto artieles in euch popular magazines as Reader's plgest, Hevereak, and Saturday Evening Post, there is very IIttle motiration for electoral reform among most comon peoplo. This may bo attributed to a number of Iacters Inoluding a misuderstanding of the present aysten of the fact thet our fortuitous history of lectoral vietorles colneldes co alosely with the popular votos. As Stephen h. Uraubard wroto in Commonweal, there Is a public laek of intereat on the subject and no real foars of the ovile of the present system. 25 For moat Amerieans, any "evils" in the present system lie outide the reeln of experlenge and therefore vield little, if any, porer. "Diseretion and common sense recommend wo spona our time and energy on more eritieal conecrns."26 This attitude is reflected in a nuber of olvie groups. The League of Vomen Voters, for example, hes mentioned the topic for oonsideration in the past several years but 
has chosen other subjects for atudy. 27 Other groups who have recommended change, such as the Chamber of Comerce of the United States, way have actualiy neutralized thoir impact by not boing specifte enough in theix recomendations. The Chamber's announced support of elther a nationwide popular rote amendmont or the distriet method anendmont could cause some to viow their actions as mexely change for the sake of ohange. In view of the many analyses of the trong the and weaknesses of varlous reform proposalu, it is rory diffieult and disconoerting to try to understand how the Chamber can consider a distriet and direet reform proponal equally acceptablo. A word hould be and, howerer, about those citizens, both in and out of Congreas, who do recognise the potentiel dangers of the prosent aystem, who approve the principlo behind the direet rote proposals, and who aro still reluetant to oneourage a change. Many aro understandably conoerned that thould one of the proposed plans be Instituted and later be found laeking, ohange might then be eren more diffleult then now. Anthony Lewis has said that "governwent is not an abstract entity 3 "28 the validaty of theory, in polities or any other field, can only be proved by adequate testing, but we all might reasonably ask whother a noeded reform under a new system might take another nine decades. This was one problem which the political realist in Kennedy pondered before 
his vigoroug attack upon the Mund-Daniel B111 in 1956. No one, of course, dare conclude that risks would never develop under direct popular election, but if one's premise is based upon an overriding constaeration of domocracy, the risk seeme worth taking. The ideal of popular cholec is the wost deeply ingreined of our governmental prinolples, 29 and eren the knowledgo that demoeratic elections oannot always guarante that the best man will win should not alter our course. As Peirco has state

Eron when we have shed the barnaeles of the leotoral college from the ahip of otate, there 1. no guarantes thet wo or our desoendents may not one day lect obarlatan or en ldeologue to the Preatdeney, 30

Ho goes on to add thet undes the present aystem we have already lectod "some pretty grim medloeritles to that oftede, $n^{31}$

But even whon one adnits thet the rox populari may orr, the fact remaine that through our entre natlonal experienee we heve learned that there is no vefor, no better wey to eleot our publie offledals than by the aholes of the people, with the man who wins the nost rotes beling awarded the offlec. This is the essonce of the conent of the governed. And no watter how wisely or loolishiy the Amertean people choose thelx President, he 18 their President. No one hus been able to how how the * qualnt 18 th century voting derloo - Ith all its potential "vild cards" can serve to protect the Republie. The ohoice of the Chies Executive must be tho pooplea', and it should rest ith pone other than them, 32

James C. Klrby, Jr*, Iat professor, momber of the 
American Bar Association' Commision on Electoral deform, and chlof counsel for the U.S. Senate's Judiciary Subcomitte on Constitutional Amendmonts, has remarked: "The instanees when the present system very nearly misfired. Indleate that the law of averages may be ready to oateh up with us." 33 ve can only hope that the price we may orentually have to pay for obange rill not be too great. 
Nond

Chapter I

IDan Golonpaul, ad Information Lloge Almanoc,

(Nov Iorkt simon and soluster, 1966), p. 261 .

Rarm Louls seldon, whe Deotoral colloge Doos

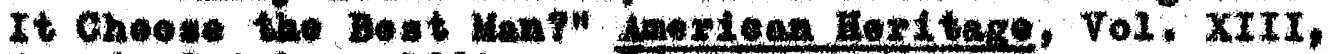
No. 6, Ootober, 1962, p. 5\%,

Iste. 9. 9.

Heltx Morloy, "Bomoeraey and the "Rectoral Collage,"

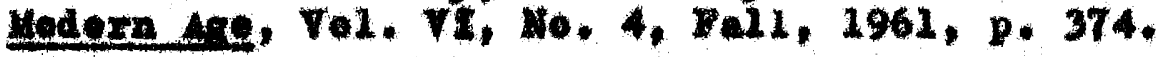

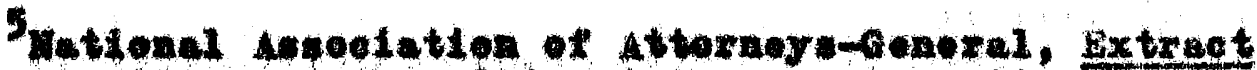

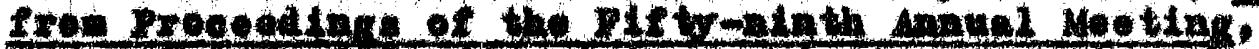

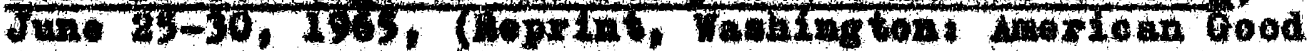
Government gestets). D. $\mathrm{I}$.

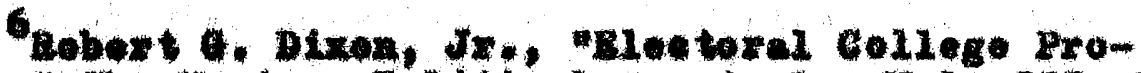

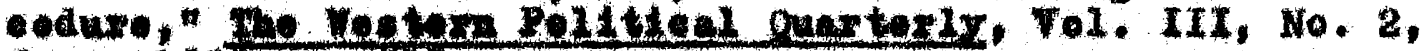
sume, 1956, p. DL.

Trte. P. 88).

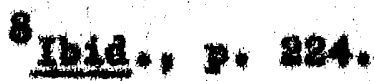

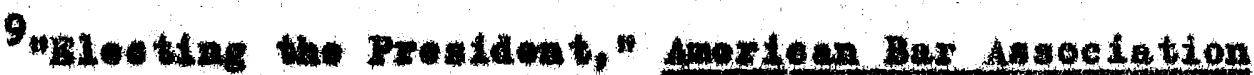

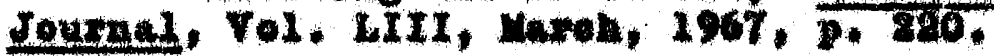

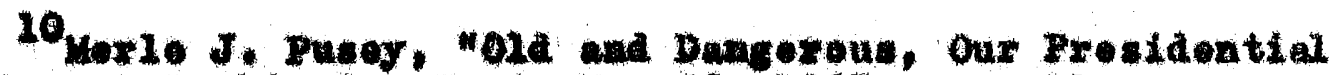

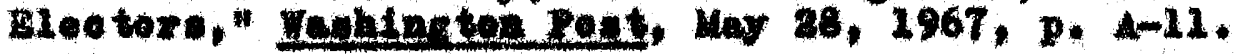

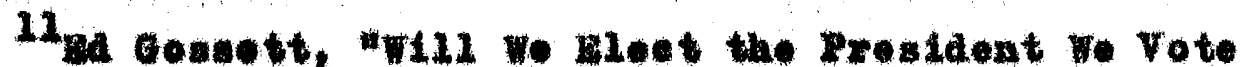

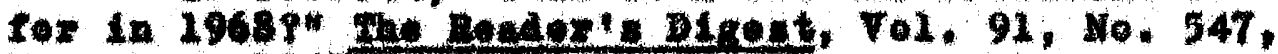
Norember, $2967, \mathrm{P}, \mathrm{me}$.

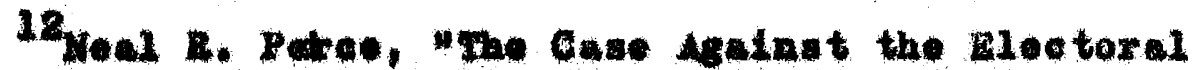

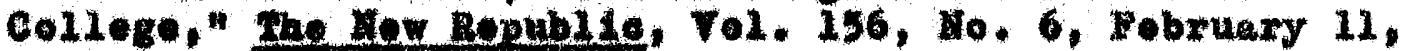
P. 12 .

13pieherd L. Strout, "A Juner thing could Happen on the way to the White House," Her Lork 2lmes Haxasine. sundey, July 23, 1967, p. 5. 
14 Ibid.

15

Ibid.

16 Robert L. Tlenken, Proposens to Relorin Oax Gleotoral systog, (Fashing ton: Librury of Congross Legisiative Raterence Service, 1966), p. 134,

17

Ibid.

18 Ibtd., p. 135 .

190.8. Congrean. Bencto. Comittee of the Judielary, The Rleatoral College, Momorand um prepured by the staft of the subeomait toe on Constitutional Amendmente, 87 th Congrese, 1et oesu., 2961, (Weshlagton, Government Printing office), pp. $32-54$.

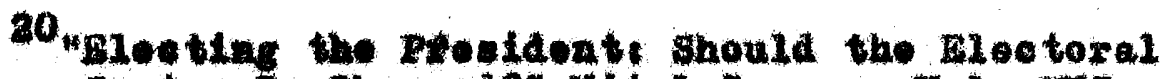
Colloge gratem De Changed?" VItal Iagued. Vol, XVI, No. 8, Apri1, 1967, p. 2.

${ }^{21}$ Conczencional perterly Deat shoet on Plootoral

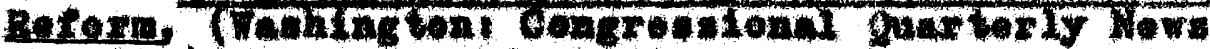
Serviee), Deentber 16, 1966.

28 nid.

23 Repreauntetive Wondell ratt, "Tobuletion of 1967

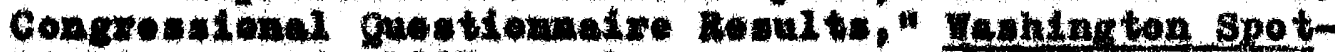
11nt, August, 1967, p. I.

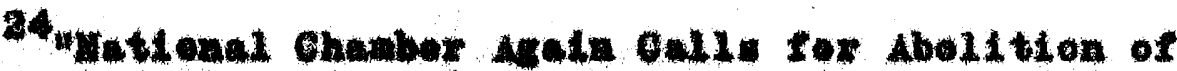

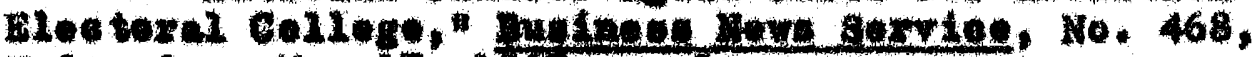
vedmeday, Hay 17, 196, P. I.

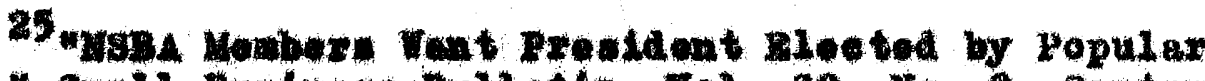

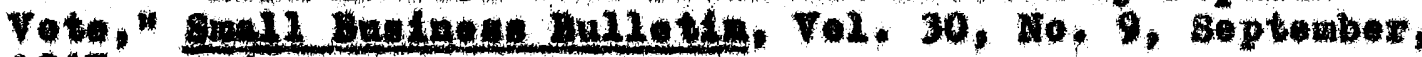
1967, 1. 4*

\section{Ghapter II}

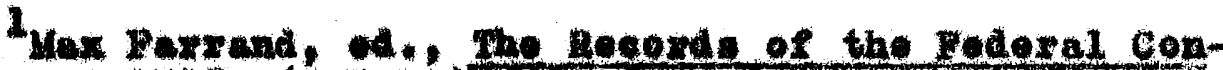

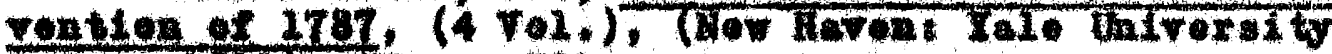
Frong, (O11), II, P. 501 .

${ }^{2}$ Luelus wilmexaing, Jx,, the Eleotorel collere (New Brunawlek, N,J, Rutgers untroraits Pross, 1958), D. 10. 
3yarrand, op.eit, I, p. 69.

4luid., p. 80 .

suld.. p. 68 .

6Ibid., II, o. 28.

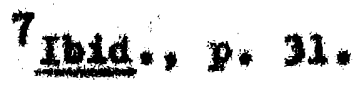

smea, p. 48 .

9uimeraing, on clt., p. 18 .

${ }^{10}$ mue. p. 5.

11 Ibid.

12 Parrand, eqe elt, 1, p. 68 .

13 mble., It, p. 403.

14 mese. p. 34.

15 med. p. 53 .

${ }^{16}$ mete, p. 218 .

17 moce., I, p. 68 .

18 Ible, II, $p, 133$.

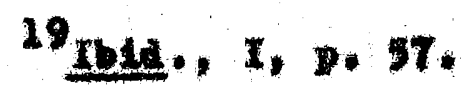

20 wilweraing, ge.elt., p.9.

21 perrand, ogedte, it, p, 109.

20. me., p. 399.

${ }^{23}$ nid.., p. 400.

${ }^{24}$ whending, ae.elt., g. 14.

${ }^{25}$ Barmand, op. Q14, II, D. 497.

26 oud.

27 note. 
28

Ib1d.. Pp. 517-521.

${ }^{29}$ rbtd., II, p. 500 .

30 Ibla.

${ }^{31}$ Ibid*, p. 522 .

${ }^{32}$ Ibld., pp. $590-603$.

33 Aloxand or Hentl ton, John Jay, and Jeme Hedison,

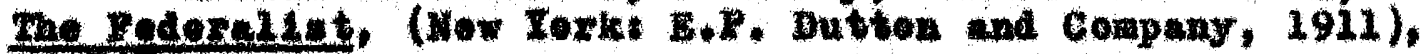
D. 34\%.

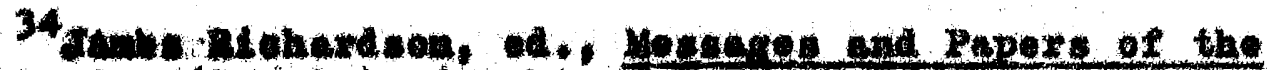

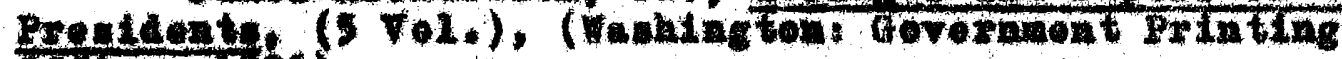
orise, 1606), I, p. 41 .

35 vilwording, ore att, D, 19 .

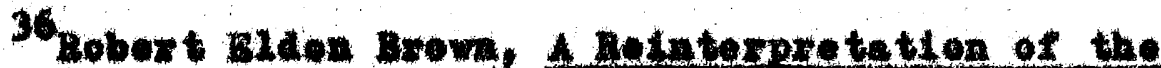

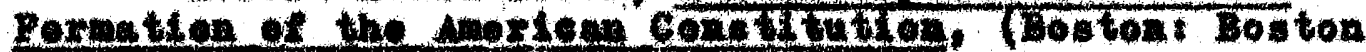

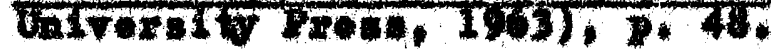

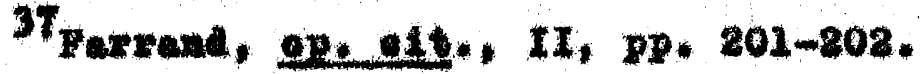

${ }^{38}$ Ibiel, p. 203.

39 Jowathen BLLfot, od, Dobeted in the sereral

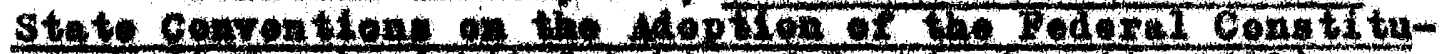

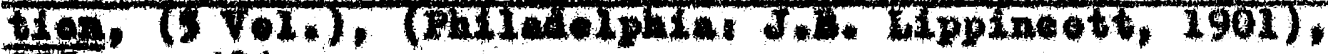
III, p. 494.

40 wimexileg, leecelt.

41 Hemil ton, Jay, Madion, op.edt., p. 237.

48 IbLe. pp. 347-349.

${ }^{43}$ bla*. pp. $237-838$.

44riliott, op. alt., II, pp. 433, 511.

45 viluexding, ope alt, p. 22,

${ }^{46}$ Hamil ton, Jar, Madion, on eit., e. 347.

${ }^{47}$ Drowa, 100. elts.

48 wimordiag, op.ept., p. 3 . 


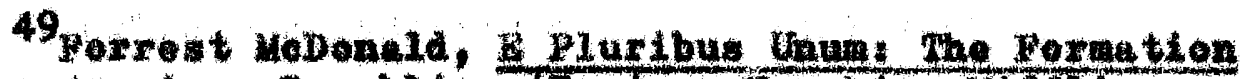
of the Anerican Republle, (Boston: houghton-Miffifn Company, 1965), p. 185 .

50 rota.

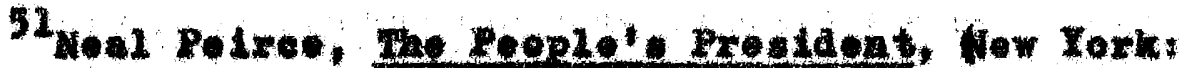
simen and sohumber, I960), p. 3 .

\section{Ghapter III}

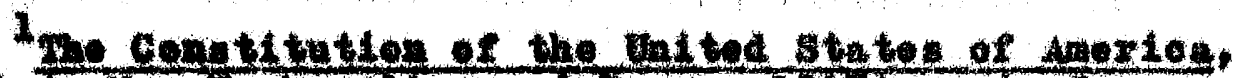

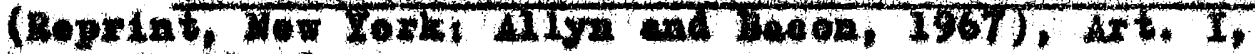
see. 4, 61. 2.

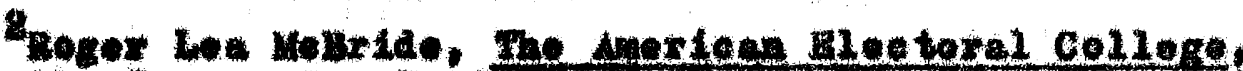

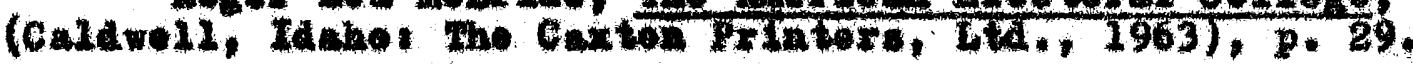

3re.

4atate porrex to Bind prosidonthal gleetors," Celunble Lex merier, V01, 65, Me. 4, ApxL1, 1965, p. 699.

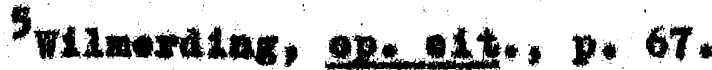

6ubride, ex. att., o, 31 .

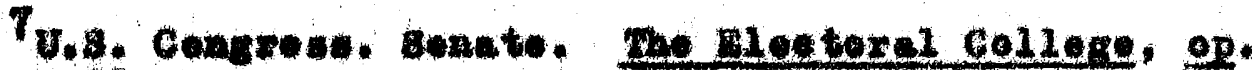
at.. p. 80.

Dre.

9 Revulte of the 1824 presidential election, Repriated In Bloetion of Prevident and Vleo-Preaident, A

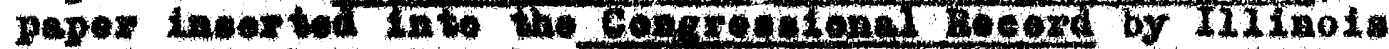

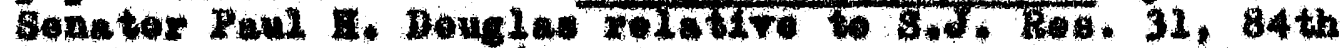

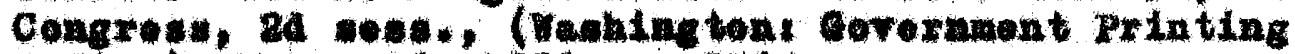
Defiee), Mareh 26, 1956, P* 5564.

\section{Chapter I}

\section{Howken, op. ett., p. 33 .}

22 coumitte on blectoral college Reform, How Should

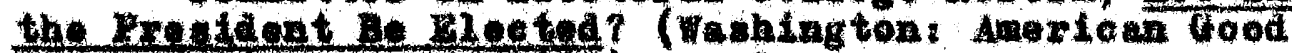
Cororamont soex ty, (961), p. I. 
${ }^{3}$ U. S. Congreas. Senate. A Jolat Besolution Relating to Nomination of Candidates for Prostent and VleeErealiont, 8.J. Ro.5. I, b7 th Congress, Ist tess., (Fieshing ton: Government Printine ofelce, 1961), p. 296.

40.s. Congreas. Seart . A Jolnt Rogolution Proposing an Amendinent to the Congtitution of tho United

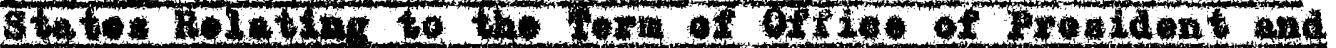

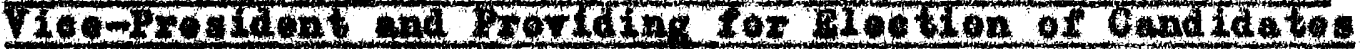
Tor Groddot and Vee- roduent by Popular Vote:

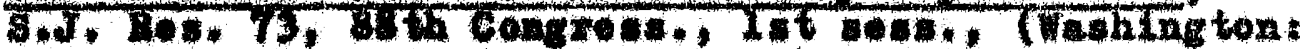
Goresument Printing offie, 1963), p. 7it3.

\section{rise.}

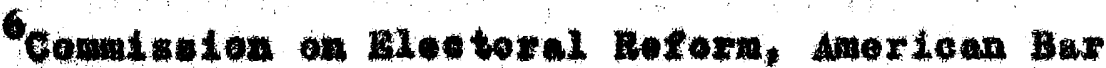
Alsoeiation, Secelt., B. 46.

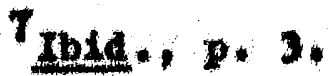

nede.

9 reld.

10 wenken, ep. elt., p. 39.

11 nda.

12. Iota.

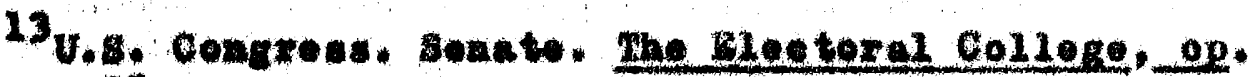
act. D. 25.

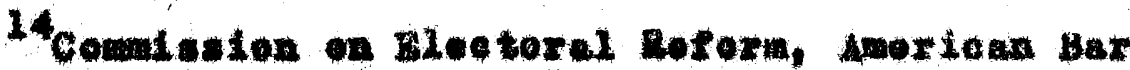
Aasooletten, en* ett., p. 45.

15 pelroe, "The Gase Ageingt the Electoral Collego," op. a1t*, p. i3.

16 Dizon, ex. At., 217.

17J. Harvie Willawe, "The Declaration of Indopendoneo-mon and Not," epeech borore the Deseendmats of the Signera of the Deciaration of Independenee, (Aloprint,

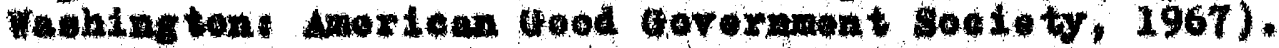

18 geldon, op. att., p. 12 .

19 quenken, one alt, p. 43 . 
20 Ibid., p* 45 .

210ol anpaud, op.elt. p. 15 .

22 Tienken, Op. eit., p. 44.

${ }^{23}$ Comitte on 1eatoral College Reform, Hew Should the Prouldent ge glocted, op. elt., p. 7 .

24 Hoel Pelree, the Hoetoral callege foes to Court," The Renerter, Vol. 35, No. 5, Oetober 6, 1966, p. 34.

25. Iuta.

26 arex ro Bandere, 372 $0.8,368,(1963)$.

27 Ibla.

20.19.

89 goven, ope at., p. 94.

$30 \mathrm{mea}$.

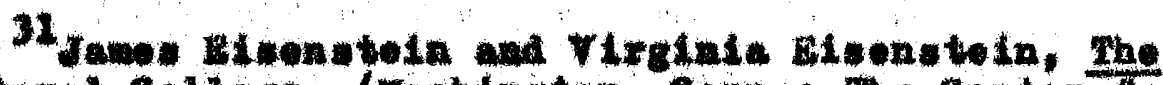

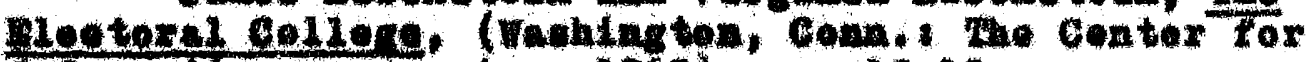
information of Amorien, 1969), Pp. 12-13.

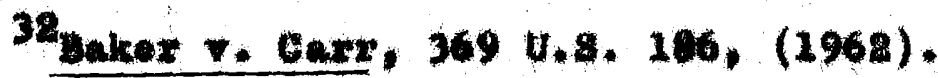

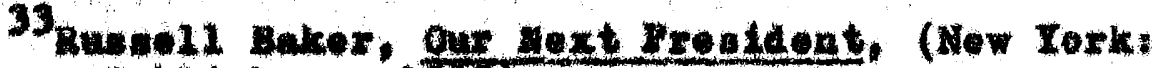
Athonew publither:, 1968).

34 comat tee on Electoral College Reform, How Should the Psesident Be gleoted, sp. elt., p. 13 .

35.gtate Powoz to Bina Prosidential Hlectors" cit., p. 700 .

36 "Three slaten Vie For oregon'. Hlectoral Votes" Election artre, (Portiand, Leacue of Momen Voters, 1968), D. I:

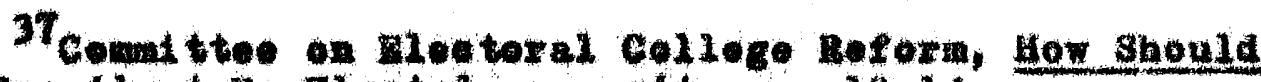
the President Ee pleeted, op. e1t., p* 13-14. att.

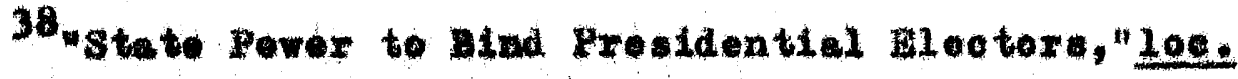


${ }^{39}$ Ibia.

40 Frod Israel, ed., State of the Union Messages of the Presideate, $1790-1966$, (3Vo1.), (Now York: Chelso Fibilshing House, 1966), III, pp* 191,203,

41"zlecting the erestatent," op. elt, p. 220.

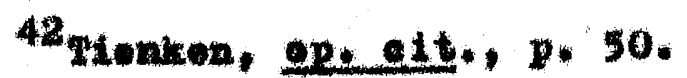

${ }^{43}$ Comalt te on Electoral Gollege Beform, How should the Preeldent Be gleated" ope alt." p* 8.

44 rie.. p. 7.

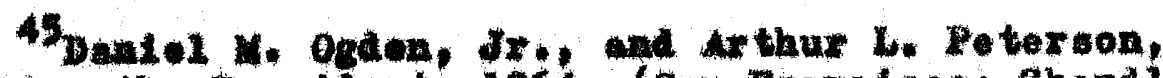

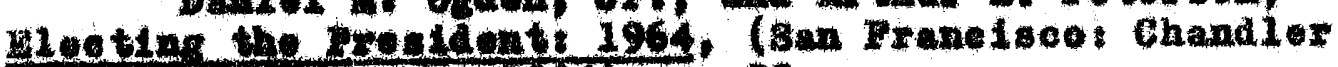
Publishine compeny, 1967, D. 22.

46 Tionkex, poratt., p. 35.

17de.

48 Rehard C. Welty, Who Rosily Mloots Our Presidenter" The Udeet ogarterly, VoL. II, No. I, Oetober, $1960, \mathrm{p}, \mathrm{3I}$.

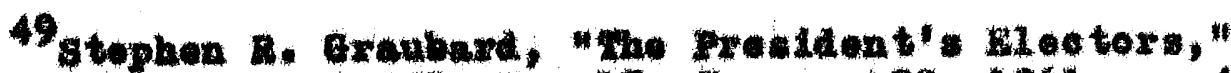
Comenvel, Vol. LXXIII, Mo. 17, January 20, 1961, p. 432.

so Ibla.

51 Alexunder H. Blekel, "The Case for the lloetoral College," The Nee Eepublie, Vol. 156, Wo, 4, Jahuary 28 , 1967, p. 16.

52 Ible.

33 reda.

54 rotd.

55.tol toe. 10it*

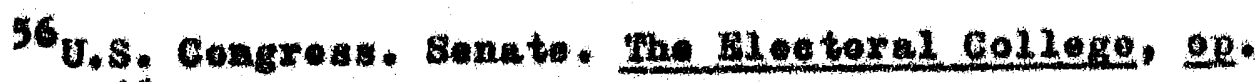
at., p. 46 .

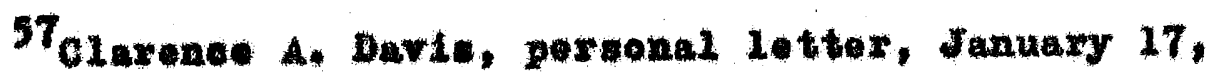
1968.

58 Pusey, op. ait, p. D-5. 
59 rbia.

60" Anmex to Wallace," The Her Republie, Vol, 156, No. 10, March 9, 1968, p. 8.

61.

Ibia.

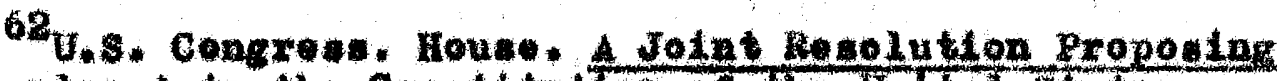
an Aneadaent to the Constit tution of the UnIted States Eole ting to the plection of the proutent and Vioe-

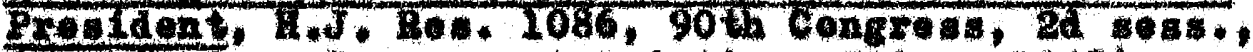
(Wobington: Govermment Printing of 160,1968 ), p. 2776.

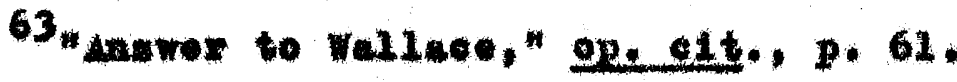

64 rienkon, op. att*, p. 62 .

$65 \mathrm{Ibla}$.

66 Blekel, op. alt., p. 26.

67 Xol aen V. Poloby and caron B. W11davikg, Erealdentlal zloctiest, (Now Yorkt Charles Soribner's Sons, 1964). D. TII.

68

Ibid., p. 172 .

69vol., one 014., p. 23.

70 Dutd., DD, 29-30.

Tholempaul, encelt.. p. 3rT.

T2 Grawbard, opeat., 433 .

73 Inte.

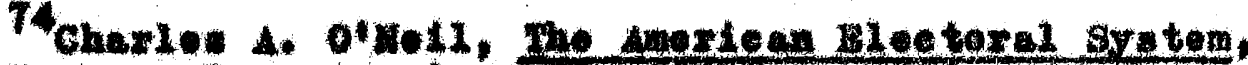

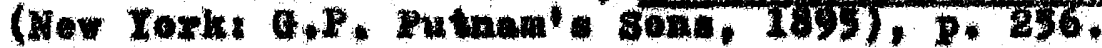

75 Ibid., p* 260 .

76 rteman, epeatt., p. 63.

77 Davis, loes edt.

${ }^{78}$ Birah Dayh, porsonel letter, Mareh $26,1968$.

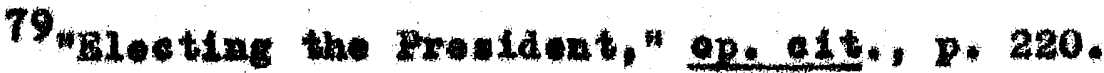




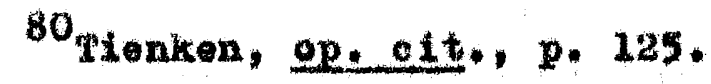

${ }^{81}$ ove 11, og. e1t*, p. 254.

82 Ibid.

83 rbld.

84 rbie.

${ }^{85}$ welty, op.elt., p. 32.

${ }^{86}$ pble.

87 U.S. Congress. Senate. the Hlectorel Colloge, Qp. edt., p. 57 .

88 Tionken, op. elt*, p. 66.

${ }^{89}$ Elogtoral College Rotorin. Moterond um No. 98, (Waming tont Chamber of Connoree of the Onited states, 1965) p. 11 .

90 ode11, ORe 014., p. 252 .

91 Moleride, opselt., p. 42.

98 sulden, ere alt., p. 18.

93 comittie on Blectorel College Beform, How Should the Prealdent Bo Bleeted" op. eit., p. 6.

94 o'foil, op. att., p. 253 .

${ }^{95}$ Hational Asectation of Attorneye-General, op. c1t., p. 4.

96 webride, ope ett, p. 42 .

97..8. Congress. Senate. The vlectoral College, op. ext., p. 51 .

98 Jame MaeGregox Burns, The peadloek of Denocrecy:

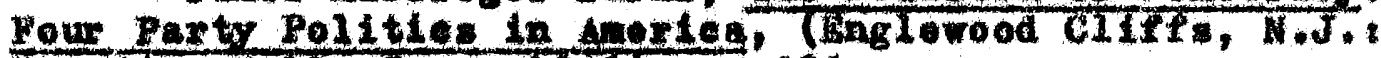
Frontice-Mall, Ino., 1963), p. 296.

99 Tienken, op. ott.. p. 71 .

${ }^{100}$ Ibld., D. 76. 
101 J. Hervie Williana, Goelltion Mow, (Tashing ton: Amexican Good Governent Society, 1966), p, 38 .

102.8. Congrass. Senate. A Jobat Mesolution Proposing an Amendient to the constitution of the Urited States Provtaling for groetion of bresldent and VieoPrealcent, s.J. Kos. 12, 90 th Congress, Ist sess., Trentucton: Goverment Printind offlee, 1967), p. 264. 103 qloaken, ere cit., p. 82. 104 Colenpan, ane at. . . 399.

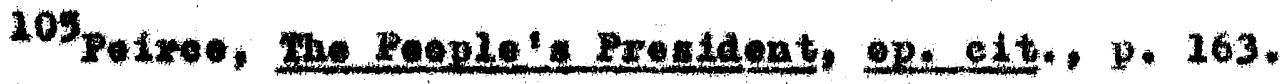
${ }^{106}$ wilmording, ope elt,. p. 145. (Lutter to James Monroe, Janumry i2, 1600.1

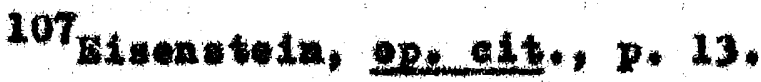

${ }^{108}$ mia.

109 Burns, ope ett., p. 303.

110 wel tor, alt., 31.

111 mble., 33 .

112.8.8. Gongreas. Senate. Meor Debates on S.J. Nos.

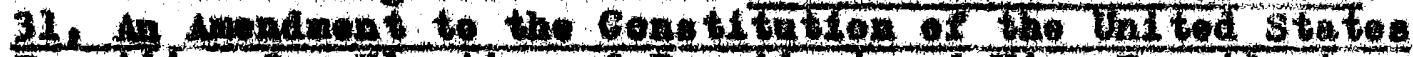

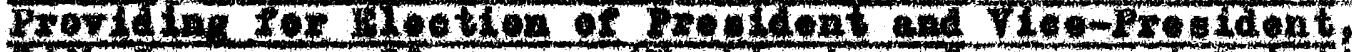

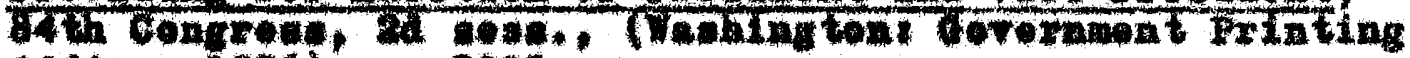
0(10\%, 1986), p. 5239.

${ }^{113}$ metd. p. 5241 .

114 IuL., pP. 5841-44.

115 nes.

116 thuras, op.c14, p. 305.

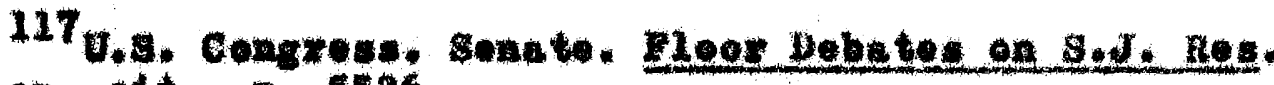
32, op, Q14, p. 5536 .

118 note.

119 Ibte.

120 saldon, op. ait., p. 96. 
121 U.S. Congreas. Sens to. Ploor Dabates on $\$ . J$. Hes. 32, ex.eit. . 5537.

122 Ibid., p. 5673 .

123 12lootoral College RePora, op. elt. p. 10 .

124 peixee, The Feople's president, op. eit., p. 165.

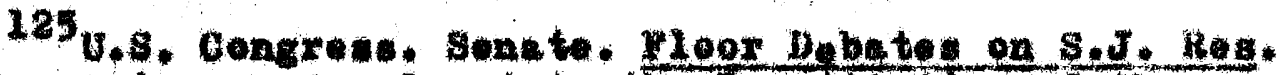
2. Propectin an anendenent to tho conetibution of the

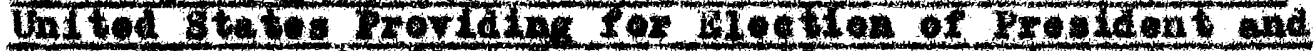
Vlee-lrecteq Governeent Palatine offiee, 1950), p. 20413.

126 gelden, lee, att.

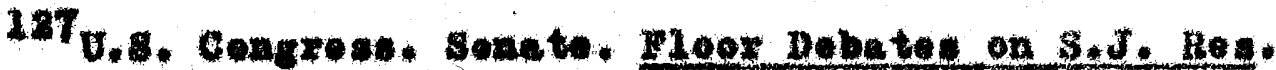
52. Prepentar on Anendnent to the conetitution of the

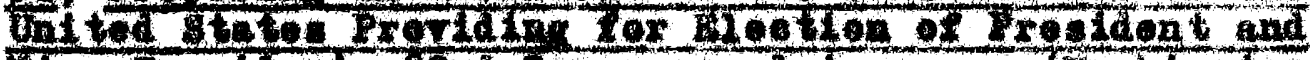

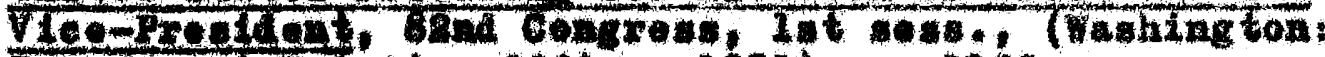

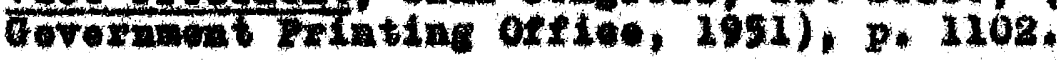

188 Ibla.

129 U. B. Congrean. Bonate Meor Dobater on S.J. Bea. 31. ar. elt.. p. 3673 .

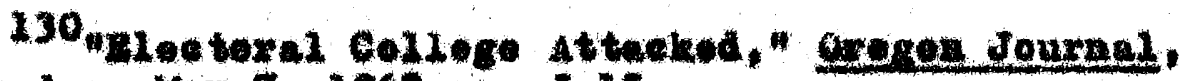
Thur sdey, Hay 7, 1969, P. J-15.

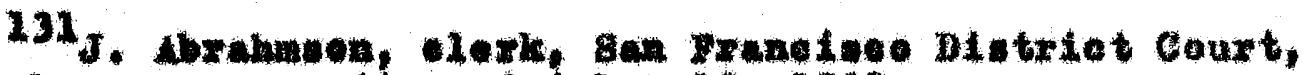
telephone cenverautien, Oetobur 10, 1968.

132. Wobride, op.ect., . 44.

133 reta.

134 notore the dectoral Collore, (Riohmond, Virginiat

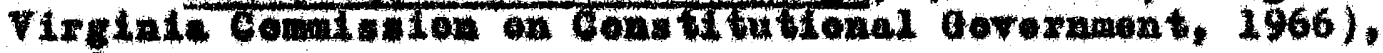
p. 9.

135 Tienken, on.eit., 103.

${ }^{136}$ wol ty, op, oft., p* 34.

137 wabride, ore eit., p, 46 .

${ }^{138}$ rbia. 
139 Luman B. Long, ed., The Morld Aluenge and gook of Facts. (Now York: Newapapox Enterprise Ansooletion, Ine., 1968), p. 905.

140 pleaken, ope cit., p. 111 .

141 HeBnide, op. cit., p. 46.

142. Ibid.. 112.

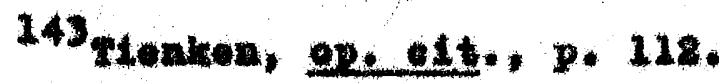

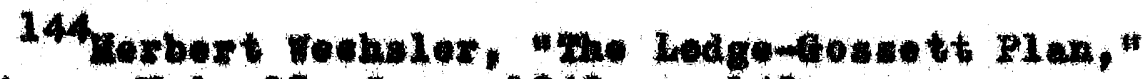
Zosture, Vol. 39, Jume, 1949, p. 140.

149 mad., p. 148 .

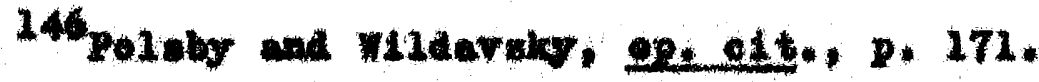

147 nus.

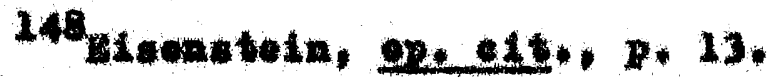

149 renker, 2, atc, p. 115 .

150 Ibes. . . 127.

152 nid.

${ }^{152}$ neta.

${ }^{153} \mathrm{bLd}$, p* 118.

154 rold.

155selden, oreate, p. 96.

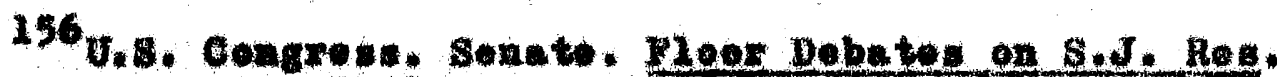
31, op. e1t., p* 5240 .

$157_{\mathrm{Bld}}$.

158 ngleoting the Prealdent, on. att., p. 43.

\section{Chepter I}

1U.8. Cengrosn. Sonet t The Glectoral cellege, op. c.t., p. 49. 
210id., p. 50 .

3 rbla.

${ }^{4}$ Ibid.

${ }^{5}$ Morley, opteit., p, 374 .

Coiree, The Feoples Prestident, Op. eit., p. 201.

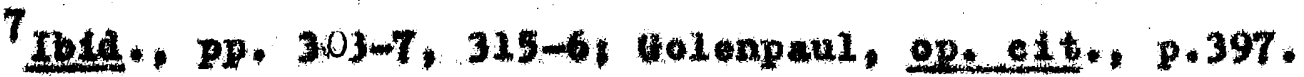

8.s. Congross. senate. Phe plectoral College, op. 1., p. 51 .

Gelonpari, exe elt., p. 534.

10 mid.. 2. 397; Polrce, the Beople's Prestaent, op. edt*, pp*304-7, 316.

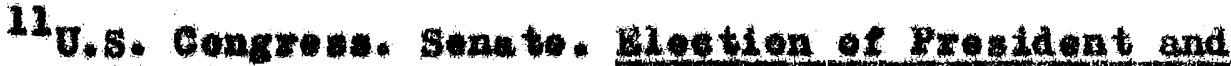
viee-Prenident, op. elt., p. 5536 .

\section{Cheptex VI}

Iporewand by now thekex in Polrce. The Peoplots Ereatent, ope elt., p. 12.

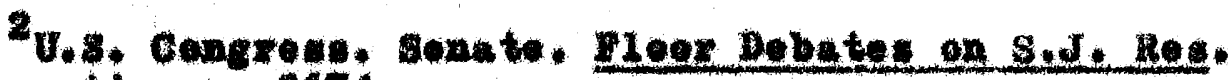
32. De att., D. 5674 .

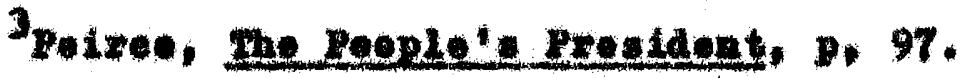

4Youl Fofres, poxsonul Lottex, April 27, 1968.

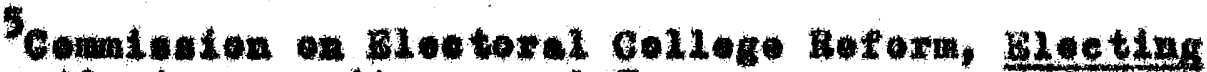
the Prealdont, ore elt., Dp. 6-7.

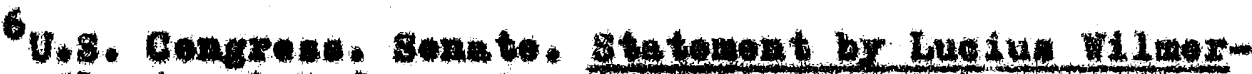

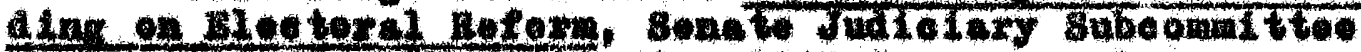

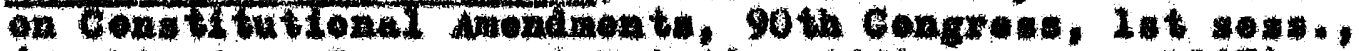
(Washing ton: Gerernatent Prinilig orfice, June, 1967), p. 5.

7wabride, op. alt, p. 44.

Sohn I. Banghat IIX, "Rotlections on the rloctoral College," Jillengere Lex Revier, Vol, 13, Wo, 2, Wintex, 1968, p. 335, 
${ }^{9}$ Ibid., P. 344.

10 ibia.

11 Ibid.

12 mla.

13 rbid., p. 345 .

14 Ius.

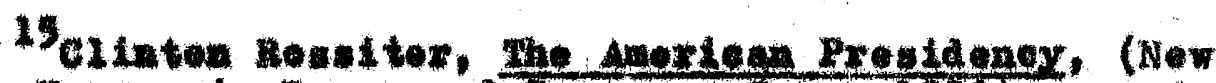

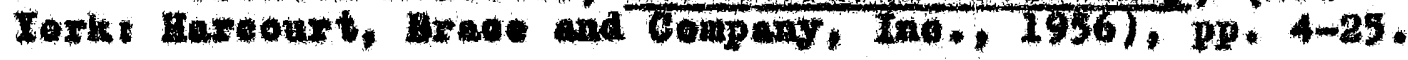

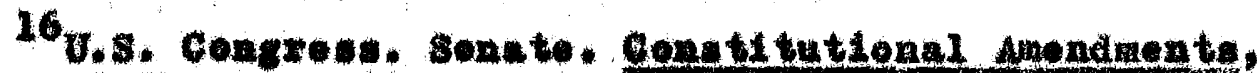

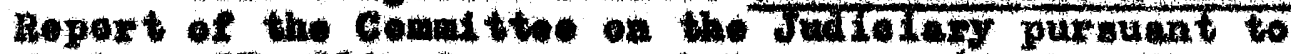
s. Ros. 57, 88 th Geagrese, lot sesw., (Washingtont

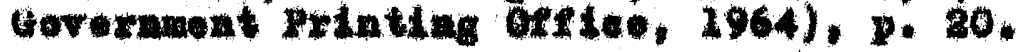

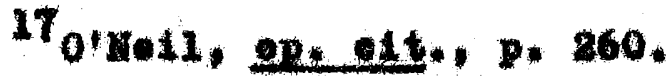

18. wimoraing, ore att, p. 212,

19vol to, on. elt, p. 34.

20" what Dirkson Kows," the Lor Republle, Vol. 158 , So. 4, Januery 27, 1968, p. 10.

al neta.

82

mid.

23

Ibete.

24

Inda.

25 Qraubard, oes ait., p. 431.

${ }^{26}$ Lomgue of Women roters of Portland, telephono converastion, March 4, 1968.

27 Anthony Lowin, "the Case Agningt Alectoral Reform, The Reperter, Vol, 23, Ho. 10, Deeember 8, 1960, D. 33.

${ }^{28}$ Polree, the Roople'e preatdent, op. elt., p. 297. 29 Db1a. 30 Ibid. 
107

${ }^{31}$ Jame C. Kirby, "Turmoil on the Electoral college Campo," The Progressive, Vol. XXXII, No, 10, October, 1968, pp. $\frac{13-16 .}{16}$ 
B LBL, IOGEAPRY

Books and Papphlete Citod

Baker, Russe11, Qur Hext President, New York: Atheneum Publiahers, 1968.

Brown, Hobert Hadon, A Belaterpretation of the Yormation of the Amorican Conetitution, Boston: Boston UnIfersity Press, 1963 .

Burne, James Heckregor, the Deedlock of Demoaracy: Pour

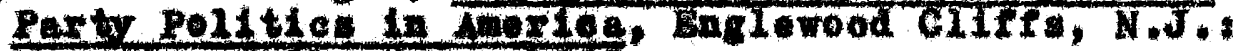
Prentra Hell, Int., 1963 .

Comalasion on Mloctorml College Retorm, Heoting the Prealdent, Chionget American Bar Asooletion, 1967.

Comint tee on Blectoral College Beterm, Hov Ghould the Preatdent Be gleetod? Washington, D.C.I American Cood dotorkanent soctoty, 1961 .

Eisenutein, Jame and Vireinia, The Electoral Collere, Vachington, Conn.: The Contox for Intormetion on Amertiea, 1965.

Blectorel Collere Refora, Referendum No. 98, Vashington, D.E.: Chanber of Comere of tho United States, 1965.

Elllott, Jonathar, od., The Dobated in the sereral state Conventions on the Acoption of the Federal Constitution, 5 Vol., Philedolphis: J.B. Lippinoot Company, 1901.

Farrand, Max, ed., The Beoorde of the Yederal Convention of 1787, 4 vol., How havent lele Ualversity Press, I9I.

Golonpeul, Dan, ed., Information Pleaso Almange, New Xork: Slmon and Sehuster, 1966 . 
Hamilton, Alexander, John Jay, and James Madison, The Eedorallet, New York: E.P. Jutton and Company. 1911.

Isxac1, Ired, od. State of the Undor Messares of the Prealdenta, 1790-1966, 3V01. Kov Tork: Chelsea TubItahing House, 1966.

Long, Lumpr, od. The Torld Almane and Book of Facts. New Tork, Hewapepor Enterpriae Assoefabion, Tno. 1968.

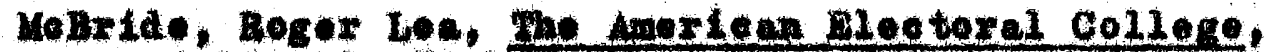
Caldwo11, Idehor the Caxton Frinters, Ltd, 1963.

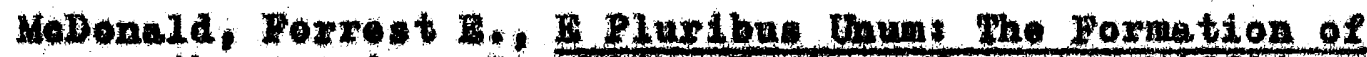

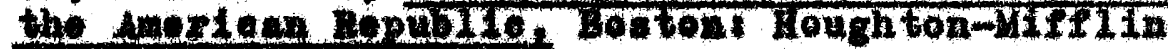
Company, 1965.

Ogden, Banled M, Js. and Arthw W. Potergon, Electing the Rrealdent, Ban Irano iseo Chandlex publishing tompany, IS64.

0'Neil, Charles A, The Ameriean lectoral Systen, Now Iork, 0.P. putnam Sona, IE95.

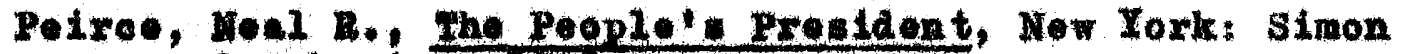
and sehus ber. 1968 .

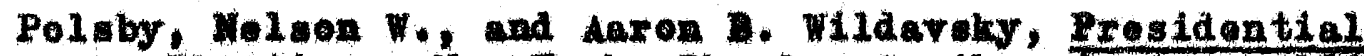
Eleations, Wow Toris Charlen SeribuerTs Sons, 1964.

Eecorm the M1ectoral Collere, Riehmond, Virginia Virginia

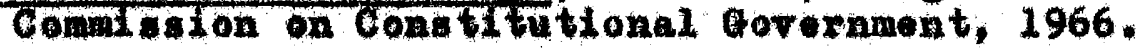

Roseboom, Rugene N, A Hitory of Predaential Rlections, New Tork: The Macmillan Compeny, 1958. 
Rossiter, Clinton, The American Presidency, New York: Hare ourt, Brace, and Conpany, Ine., 1956.

The Constitution of the United Stated, New York: Allyn and Bacon, Heprint, 1967.

Tlenken, Robert L., Eroposal te Heform our Electoral Syatem, Nahington, D.C. Library of Congress Legislative Referenee Serviee, 1966.

Williams, J. Haxvie, Coalltion Now, Washington, B.C.: Anericen Good Cotermment \$oelety, 1966.

Wilmerding, Lueitus, Jr., The gleotorel College, New Brunswiok, N.J, : Hutger: Unirersity Fress, 1958.

\section{Perledigule Citad}

"Answex to Vallaee," The YeV Republle, Vo1. 158, No. 10, March 9, 1968, p*8,

Banzbar, John Y. III, "Rekleotion" on the Electoral College," Vilienove Lev Rovier, Vol. 13 , No. 2 , Winter, 1968, pp. 303-346.

Blekel, Alexander M., "The Case for the Hectoral College," The Your Republio, Vol. 156, No. 4, Januaxy 28, 1968, PD. $15-16$.

Commission on Electoral College ReForm, "Blecting the Prestdent," amertean Ber arsocletion Journal, vo1. 53, March, 1967, Dp. 219-224*

"Congreasional quarteriy Paet sheet on Electoral Ref orm," Weshington, D.C.: Congressional guarterly News Sertilee, Decembor 16, 1966 * 
Dixon, Robert G.. Jr., "Hloctoral College Procedure," The Mestern Politieal quarterly, Vol. III, No, 2, June, 1950, pp, 214-224.

"Blooting the President: Should the Blectoral Collego System Be Changed?" Vital Issues, Vol. XVI, No. 8, Apri1, 1967, pp* 1-4.

"Bleotaral College Attaked," The Oregen Journal, Vol. 67, No. 50, Tuesday, May 7, 1968, p. J-15.

Gosett, Bd., "Will Wo Bloet the President Wo Voto for in 1968?" Beadex's Dlgest, Vo1. 91, No. 547, November, 1967. pp. 211-216.

Graubard, stephon R., "The President" Electors," Commonweel, Vo1. LXXIII, No. 17, January 20, 1961, pp. 431-433.

Kirby, Janes C., "Tuxmoll on the glectoral College Campus," The progrensive, Vol. XxxII, No. 10, Oether, 1968, PP. 13-16.

Levis, Anthony, "The Cawe Against Electoral Reform," The Beportex, Vol, 23, No, 10, December 8, 1960, pp, 31-33.

Morley, Felix, "Demoeraoy and the Eleeteral College," Modern Ase, Vol. 5, No. 4, Zail, 1961, pp. 373-386.

"National Chamber Again Calls tor Abolition of Electoral College," Businese News Servioe, No. 468, Chamber of Commere of the Unted State: Hednesday, May 17, 1967, pp. 1-2,

"NSBA Momber: Want President Eleeted By Popular Vote," Small Business Bulletin, Vol. 30, No, 9, September, 1967, p. 4. 
Peirce, Neal R., "The Case Against the Hectoral College," The New Republie, Vol. 156, No. 6, Pebruary 11, 1967, pp. 12-13.

"The Electeral College Goes to Court," The Reportex, Vol. 35, No. 5, Oc tober 6, 1966, p. 34 .

Pusey, Merlo J., "0ld and Dangerous, Our Presidential Heetors," Wouhtastor Peet, May 28, 1967, p. A-11.

Seldon, Harry Lovis, "The Eloetonal College: Does It Choose the Bost Man I" Ameriean Heritage, Vol, XIII, No. 6, Oatober, 1962, D2, 12-19, 92-96.

"State Power to Bind Presidential Electors," Columbia Law Eerles, Vol. 65, He. 4, Apr11, 1965, pp. 696-709.

Strout, Riohard L., "A Funny Thing Could Happen on the Vay to the Whit te House," He York Mimes Magazine, Sund ay, July 23, 1967, pp. 24-25.

"Three Slates VIe for Oregon's Blectoral Votes," ploction Extre. League of Women Voterw, 1968, p. 1 .

Tobin, Richard L., "Why 2968 Is a Dangerous Yoar," editorlel, Batarder Beviex, Vol. $\mathrm{L}$, No. 4, Octobor 7, 1967, p. 26.

U.S. Congrews. Sone to Propened Constitutional Amendment to Abolish the Eleetercl Collore, S.J. Res. $2,81 \mathrm{st}$ Cong.. Ist sons.. Washingtont Government printing offlee, 1949.

- Rloor Debates on S.J. Des, 2, Amendment Proposing an Amendment to the constritution of the Uni ted

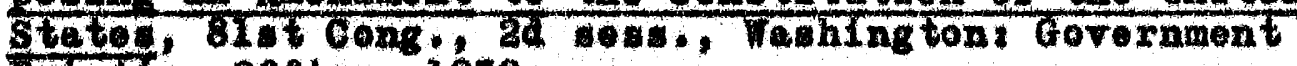
Fintring offlee, 1950 . 
- Floox Debates on S.J. Res. 52, Proposing an Amendment to the Constitution of the United State Providing for Flection of President and VicePregldent, 82na Cong :, Iat sess ., Vahington: Government Printing offiee, 1951 .

- Door Debates on S.J. Hes. 31. An Amendment to the Constitution of the datted states Providing Tor Election of Tresident end Viee-Prestaent. 84th cong, 24 ass., Teqhingtont forernment PrintIne orfec, 1956 .

- Bleotlon of President and Vlee-Prosident, A paper taserted into the Gondresstonel Record by IIInois Sonator Feul H. Douglae relative to $\mathrm{S} . \mathrm{J}$ Bes. 31, 84th Cons, 2d sese., Weshington: Govornment Printing office, 1956.

- Jolnt Reglution Melating to Nonination of

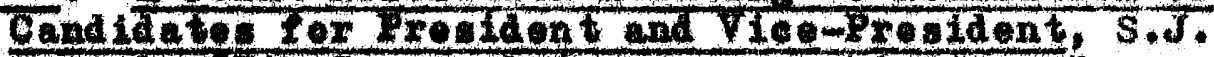
Ees. 1, 67th Cong. Ist sest, Tashington: Governmont printiug offion, 1961.

- Comat tie on the Judlelery. The Electorel Collese. Menerendum prepered by the taff of the Subeomit to on Constitutlonal Amendments, 87 th

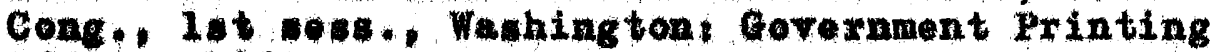
otelee, 1961 .

A Jolnt Recolution Proposing an Amendment to the Conetintien of the thited States Providing for Lontration of candidates for Presldent and Teo-Problante and for dection of Such bandidatos by popuar Jote. S.J. Res. 1, 86th Cong ist sess, Wanington Government printing offlce, 1963.

A Jolnt Rogolution proposing an Amondment to the Contitution of the Unt ted stetes lielating to Ioxm of ortac of Eresident and Vies-iresident and Frovalng for toction of Candidatos for Fresleent and Vie-preslent by popular Voto, S.J. Tea. T3, 86th Cong*, 1Et segs., Fashing ton: Government printing office, 1963. 
- Condtlutional Amendmonte, feport of the

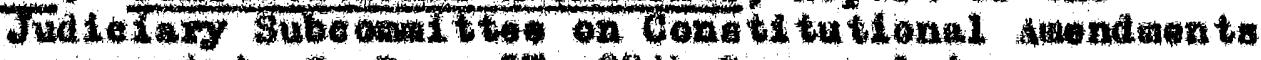

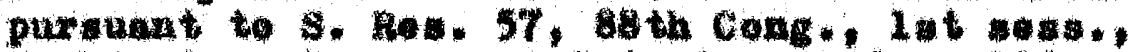
Wabing ton: Gowarnment Printiag orilee, 1964.

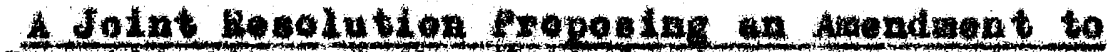

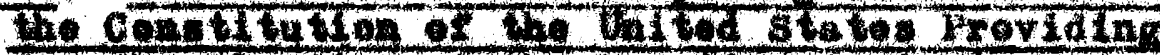

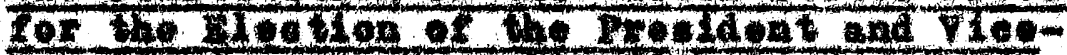

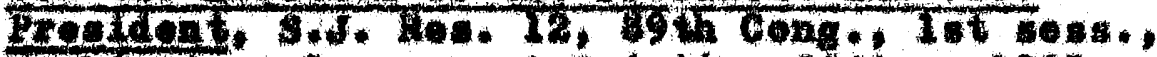
Tathingtont Governatent Printing office, 1965.

Hoint Reglubion to provide tor Direct

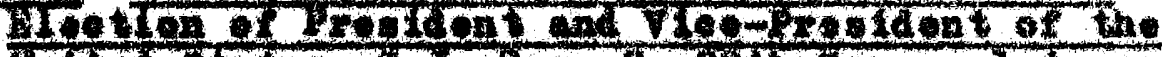

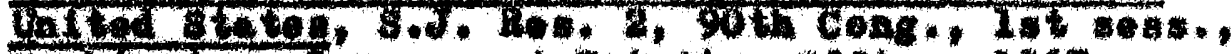

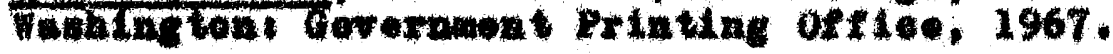

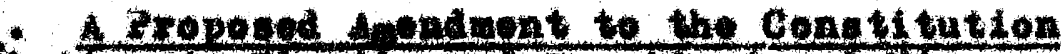

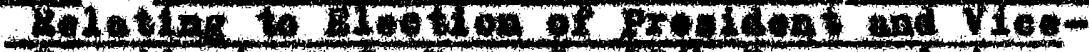

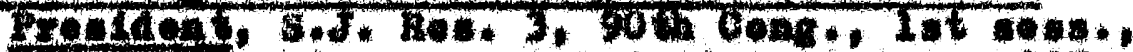

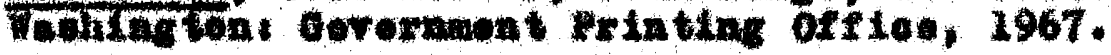

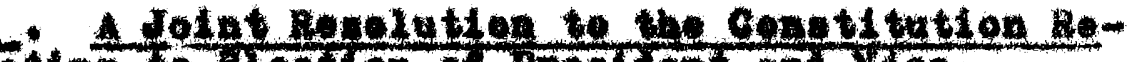

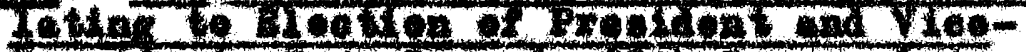

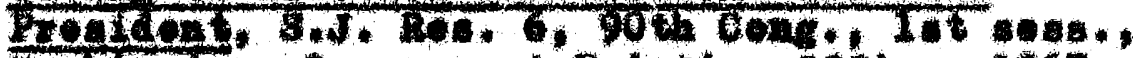

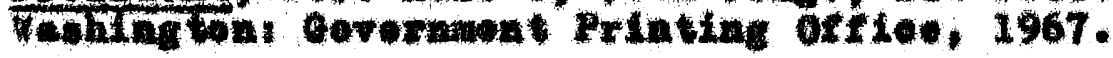

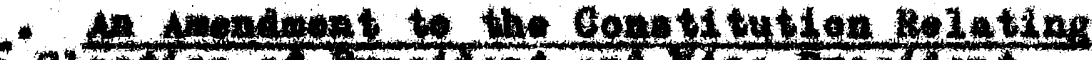

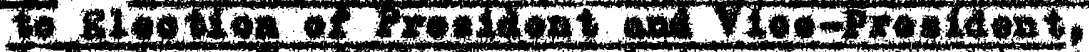

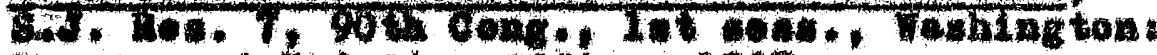

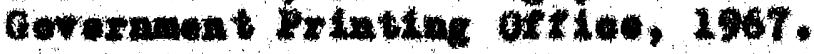

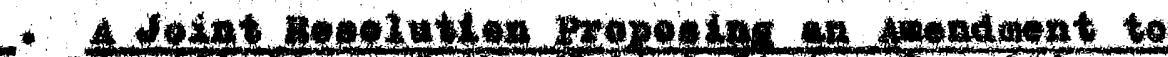

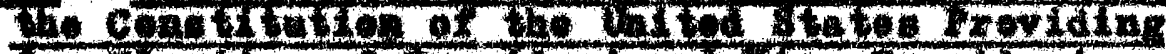

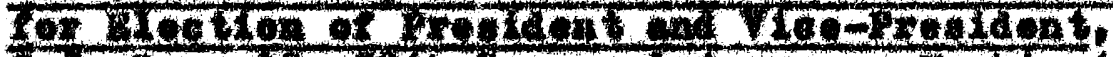

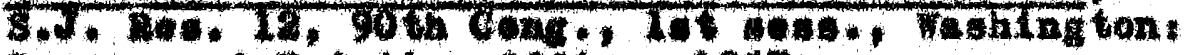

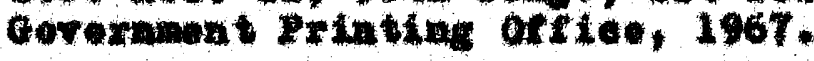

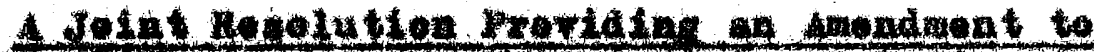

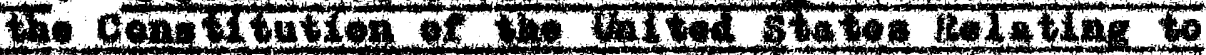

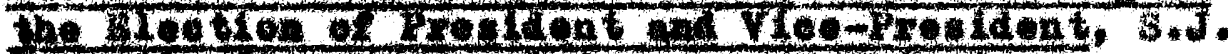

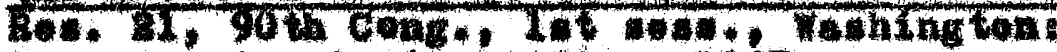

corernment Pulatibs oftles, 1967. 


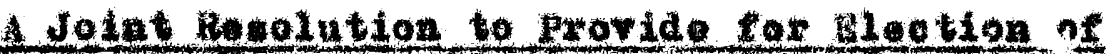

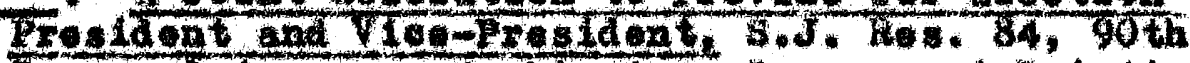

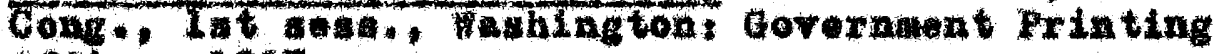
otriog, 1967 .

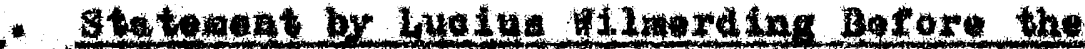

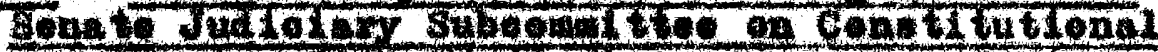

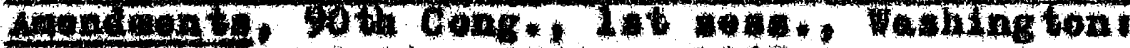
Corornion printing ortioe, 1967.

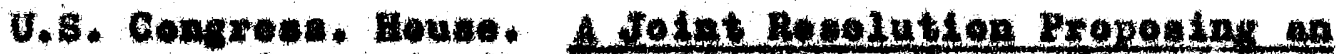

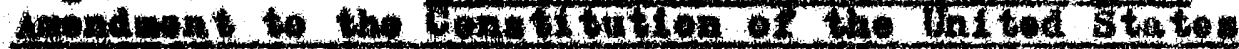

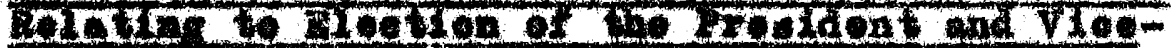

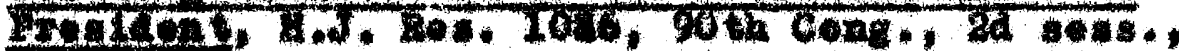

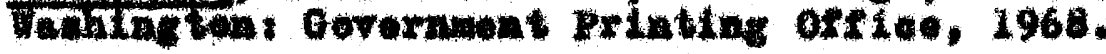

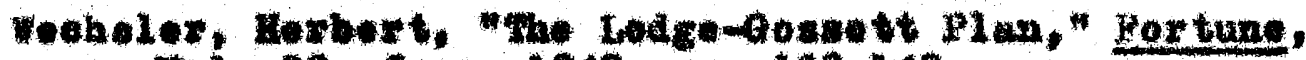
V1. 39, Jume, 1949, Dp. 138-140.

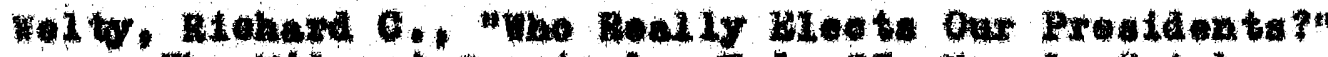

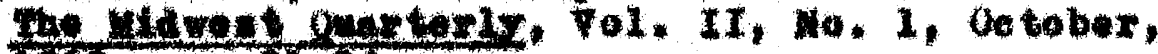
1960,

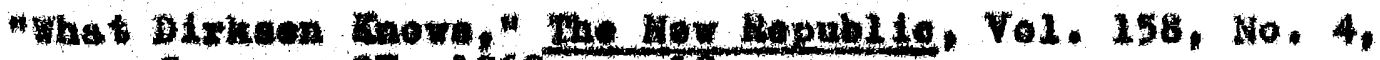
January $87,1668,7 * 10$.

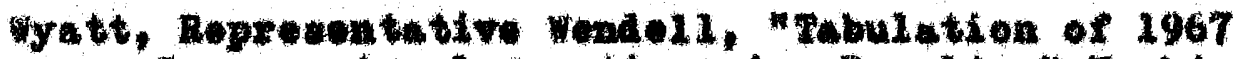

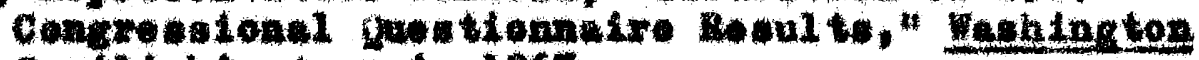
Sobutah, Angut, 1967 .

\section{Othat sowron}

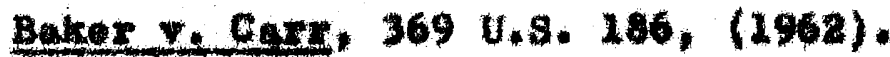

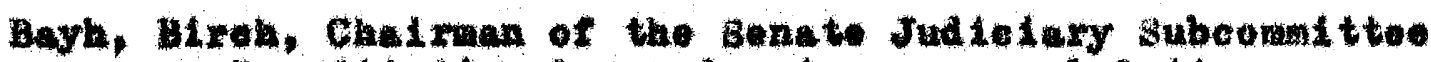
on Conebltutienal uondunts, perwonal lettex, Warah 26, 1968. 


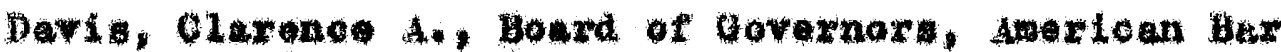
Absoelution, Wineoln, Kobraske, parsonal lettex. Jenuary $17,196 \mathrm{~h}$.

Grav Y. Sandere, 373 0.5. 368, (1963).

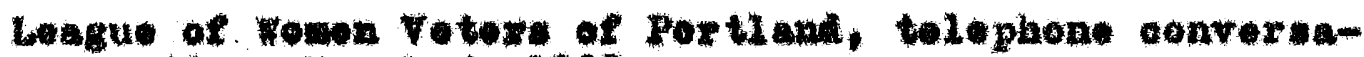
Lion, Mareh 4, 2968.

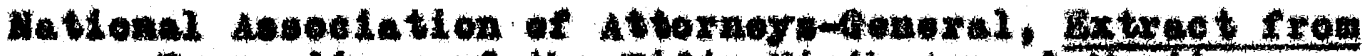

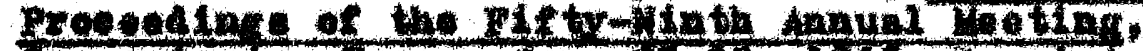

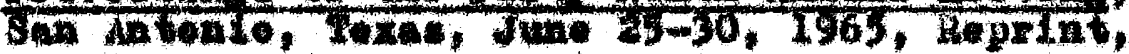

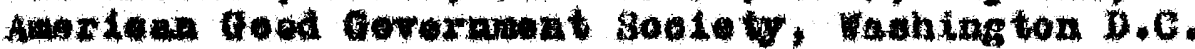

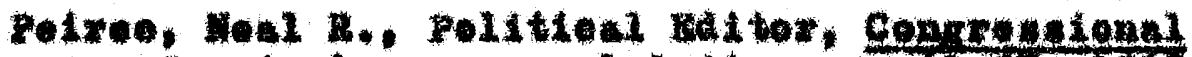
beasterlx, porsenel lettox, AprII 27, 1968.

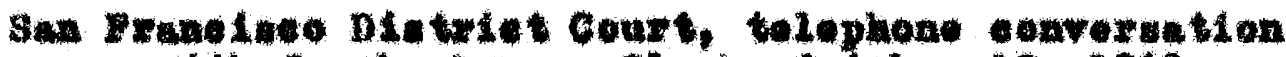
with J. Abrabuson, Clerk, Dobober 10, 1968.

Hilliene, J. Nerrie, "the Deoleration of IndepondenceThan and How," apooeh before the Desendents of the stgaers of the Deelerstl on of Indepondenoc, Aneapeifie, Hary lapd, outober 28, 1967, Roprinted

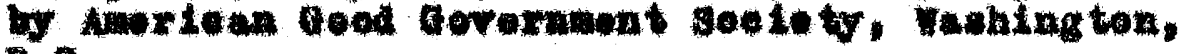
D.C. 


\section{Hoaks Consul tod}

Aly, Bower, ed, Selecting the Prealdent: The MrentySeventh Annuel Debato Lendbook, Columbia, Mis souri: Arterart Freas, 2 Vol." 1953.

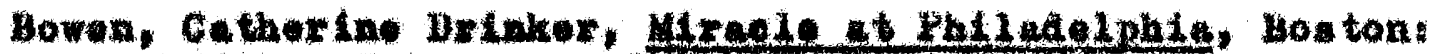
Litti., Browa, and corapany, 1966.

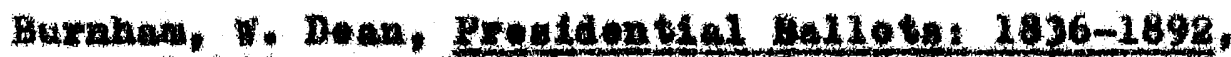

Bel thwore: whe Jases Hophins Freas, 1955.

Hutamox, Jan, ed. Gongtitutioned Chaft, Now York: Columbie Uatrorato Prose, 194.

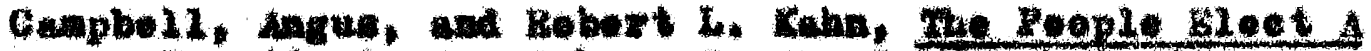

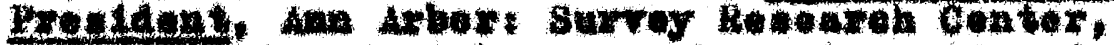

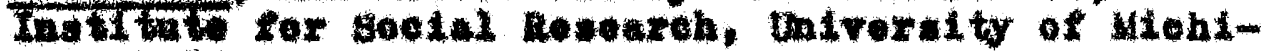
can, 1958 .

Cowall, Margaret, the Maghlaoxy of the United states

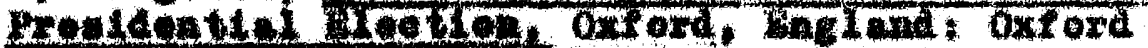
viniverato lrobs, 1960.

Daniele, Valtex M, Aresiantiel Meatlon Retoring, the

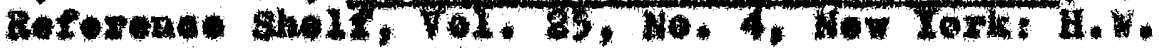
Hien Company, 1953 .

Furrand, Max, The Frenter of the Conetitution of the Hoited

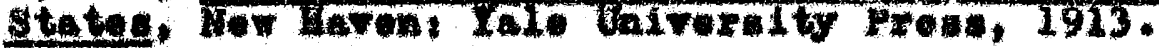

Oray, Lee Lemmer, How We Choede A Pregldent, Wow York: St. Hartin': How, T964.

Jonnings, M. Koat, and L. Hareon Zelglex, eds., The Electoral

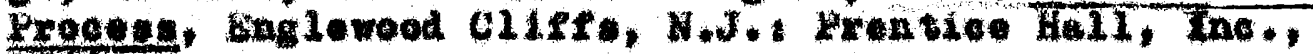
1966. 
Johnson, Julla the Heference she1f, Vol, 1 , Ko. 4, Mew lork: H. Wilson Company, 2949 .

Kallenbaoh, Jaseph D, The Anerioan Chlat gxecutive, Now Yorke Harger and How, 1966.

Leedhan, Charles, Gur Chanding Cengtl tutlon, Wew York: Dode, Haed, had Company, 1964.

Bropesed amendente to the Constitution of the United Statee, Weanington! Gorerament Erinting offloe, ISST.

Lobinwon, Edgaz Bugene, the Preaidential Vote: 1896-1932, stantord, Calleomint Staniord university Press, 1947.

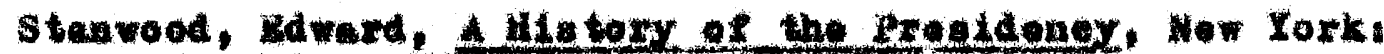
Houghton, Hitritn Colepany, 1898.

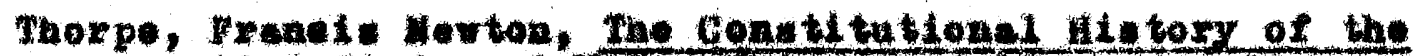

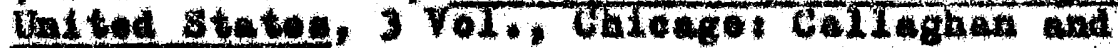
Company, 150I.

Tugwell, Hexford G., the Enlerroment of the Predidoner, Gaxden CI ty, M.I.I Doubloday and Compeny, 1960.

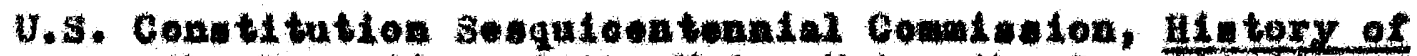
the pormation of the Unien under the constitutron.

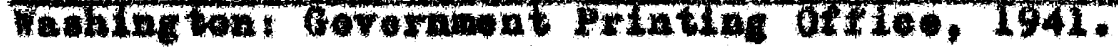

Van boron, Cerl, me Oreat Bebenterl, Wow York, Viking Proan, 1948 .

Young, Allred, ad. The Debete orer the constitution,

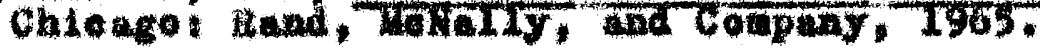

